\title{
Uranium Mineralization in Shear Zones: An Overview
}

\author{
Gehad M. Saleh \\ Nuclear Materials Authority, P.O. Box 530, El Maadi, Cairo, Egypt.
}

Corresponding Author: Gehad M. Saleh, Nuclear Materials Authority, P.O. Box 530, El Maadi, Cairo, Egypt.drgehad_m@yahoo.com

\begin{abstract}
The before mentioned activities led to the definition of three encouraging uranium occurrences in the granite; and metamorphic rocks of the Eastern Desert of Egypt. These are, G. Qattar occurrences (Northern Eastern Desert), G. El Missikate, and G. El Erediya occurrences (Central Eastern Desert), Abu Rusheid and Sella occurrences (Southern Eastern Desert). Abu Rusheid area is bounded from east and west by two sub-parallel master left-lateral strike-slip shear zones; namely, Nugrus and El Gemal shear zones. The area is crossed by N-S to NNW-SSE trending extensional strike-slip fault shear zones with oblique left-lateral dislocation brittle features and ends on the Nugrus shear zone. In addition, the detailed field study recorded the development of ENE-WSW to E-W and/or NE-SW array of strike-slip faults with oblique to dip slip reactivation evidences. The cataclastic rocks of the study area are cross-cutting by three shear zones parallel and perpendicular to each other taking NNW-SSE and ENE-WSW directions. Two brecciated discontinuous shear zones (NNW-SSE and ENE-WSW) crosscut the cataclastic rocks. Lamprophyre dykes (0.5-1.0 $\mathrm{m}$ in width and 0.5-1.0 km in length) bearing mineralization (REEs, $\mathrm{Zn}, \mathrm{U}, \mathrm{Cu}, \mathrm{Sn}, \mathrm{W}, \mathrm{Ni}$ and $\mathrm{Pb}$ ) were emplaced along the shear zones.

Uranium mineralization in the El Missikate - El Erediya area, Central Eastern Desert, has been affected by both high temperature and low temperature fluids. Mineralization is structurally controlled and is associated with jasperoid veins that are hosted by a granitic pluton. This granite exhibits extensive alteration, including silicification, argillization, sericitization, chloritization, carbonatization, and hematization. The primary uranium mineral is pitchblende, whereas uranpyrochlore, uranophane, kasolite, and anunidentified hydrated uranium niobate mineral are the most abundant secondary uranium minerals.

Secondary uranium mineralization is controlled by shear zones in which the degree of fluid-rock interaction was very high and argillic alteration is abundant. The argillic alteration, represented mainly by kaolinite and illite, played an important role in uranophane precipitation within the altered parts of the Gattar granites. Presence of calcite as void-filling in association with uranophane within the shear zones of Gattar granites may indicate that uranium was probably transported as uranyl-carbonate complexes. $U$ could be removed from solution through dissolution of feldspar, formation of clay minerals and subsequent precipitation of uranophane.

El Sella granite is highly fractionated of HKCA magma (High-K Calcalkaline) comprises primary muscovite and represents a granite pluton $\left(80 \mathrm{~km}^{2}\right)$ which was highly affected by weathering processes where the granite appears as isolated "relatively" small masses. The recording of numerous magmatic facies which injected in the area, started by the fine-grained granite enriched in uranium. The microprobe analyses proved the presence of easily leachable (low thorium) primary uranium mineral represented by pitchblende as well as autunite, coffenite and uranophane as secondary uranium minerals. Some features indicate that the late hydrothermal activities in the mineralized shear zone (ENE-WSW) played an important role in exceeding the U-potentiality. The genesis of uranyl mineralization in the Sella area supports the use of apatite-based technologies for $U$ remediation in an oxidizing environment.
\end{abstract}

Keywords: Abu Rusheid, Cataclastic rocks, Discontinuous shear zones, Secondary uranium minerals, El Sella granites, Gattar granites, El Missikate - El Erediya area.

\section{INTRODUCTION}

A shear zone is a tabular to sheet-like, planar or curviplanar zone composed of rocks that are more highly strained than rocks adjacent to the zone. Shear zones have certain characteristics that permit us to recognize them in the field, in thin section, and on geologic maps and cross sections. The distinguishing characteristics vary, depending on whether the shear zone formed under brittle, ductile, or intermediate conditions. A fault zone is a shear zone formed under brittle conditions. Displacement 
is taken up on a network of closely spaced faults. When shear zones form under ductile conditions, deformation is accompanied by metamorphism and produces rocks with foliations, lineations, folds, and related features. Some shear zones develop under conditions that are intermediate between strictly brittle and strictly ductile deformation. These may consist of zones that are partly faults and partly ductile shear zones, and may have formed in interlayered rocks with contrasting strengths (Billings, 1972, Davis \& Reynolds, 1996, Davis, 2000 and Gash, 2001). Geologic structures in the most general sense include all parts of the Earth's crust where the properties of the rocks either vary from place to place (i.e. they are heterogeneous); or vary with direction (i.e. they are anisotropic). That includes a lot of structures that can be conveniently either primary - formed at about the same time as their host rock, or secondary - imposed on older rocks (form after a rock's genesis) as a result of displacement, deformation, or dynamic metamorphism. Displacement occurs when an applied force causes a rock mass to move, Deformation is the process by which rocks respond to stress (applied force per unit area). The deformation process causes strain (change in geometry) as recorded by deformed primary features called strain markers. Dynamic metamorphism (recrystallization during deformation) produces fabrics and textures. Fabrics are spatial orientation patterns such as aligned elongate or platy minerals; slaty cleavage is an example. Textures are spatial distribution patterns; for example, post-deformation growth of polygonal, strain-free grains produces annealed texture.

\subsection{General Characteristics}

All shear zones reflect a localization or concentration of deformation into a narrow zone. The presence of a shear zone indicates that within a given deforming rock mass, the distribution of strain was heterogeneous rather than homogeneous. As a result, shear zones are characterized by spatial gradients in the amount of strain. The amount of strain is generally highest within the center of a shear zone, decreasing outward into the wall rocks adjacent to the zone. If the decrease in strain away from the zone is gradual without any distinct physical break, the shear zone is considered to be continuous (Fig. 1A). Continuous shear zone most commonly form under ductile conditions, where the rocks flow in the solid state without loss of cohesion. If the decrease is more abrupt, the zone is considered to be discontinuous (Fig. 1B). In most discontinuous shear zones, strongly deformed rocks within the zone are juxtaposed against much less deformed rocks along a sharp physical break or a very thin band along one or both margins of the shear zone (Twiss and Moores, 1992).
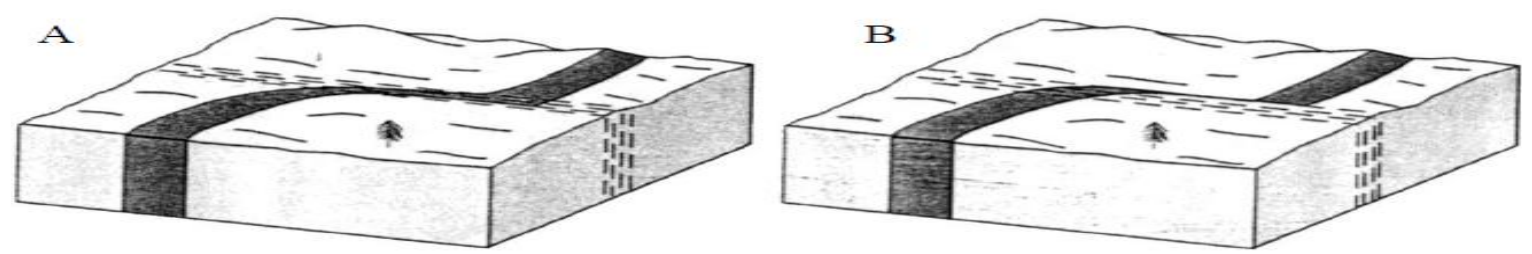

Fig1. Continuous and discontinuous shear zones: (A) continuous shear zone deflecting a marker that passes uninterrupted through the shear zone. (B) Discontinuous shear zone that truncates a marker.

\subsection{Geometries}

Shear zones are typically planar to gently curved, but some can have complex geometries. Most shear zones have subparallel margins and retain a fairly consistent thickness over much of their length (Fig. 2A). Where the margins diverge, the shear zone becomes wider (Fig. 2B). widening is most common near the ends of a shaer zone, where strongly deformed rocks within the zone grade into a wider zone of less deformed rocks. A shear zone may also thin or taper as the margins converge, such as where a shear zone passes near or between rigid objects (Fig. 2C).
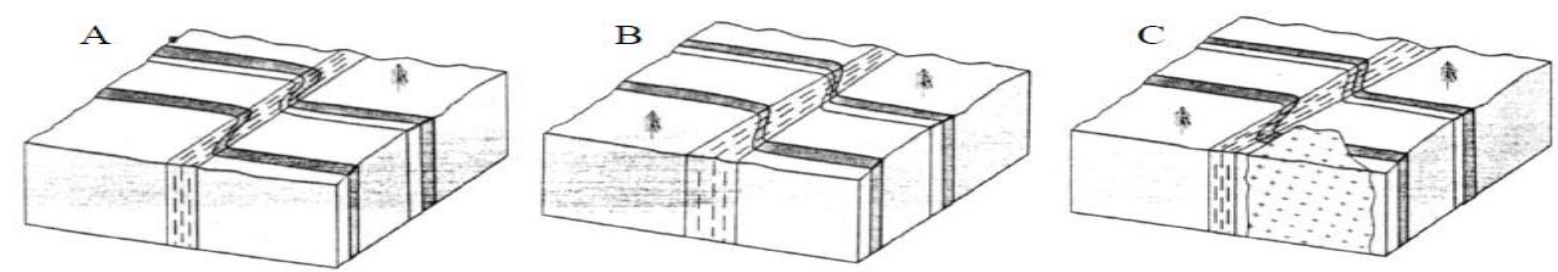

Fig2. Shear zone margins: $(A)$ parallel, $(B)$ diverging, and $(C)$ converging near a rigid pluton. 
Shear zones are commonly arranged in networks or sets composed of a number of individual shear zones. They may occur in subparallel sets, may deflect toward one another and link up in an anastomosing pattern, or may crosscut and displace one another (Figs. 3A, B \& C). Some shear zones have a curviplanar or folded geometry. Such a geometry may indicate that an originally planar shear zone (Fig. 4A) was folded or warped by subsequent deformation (Fig. 4B). Alternatively, many shear zones form with an original curviplanar geometry, encompassing and warpping around more rigid, less deformed objects (Fig. 4C).
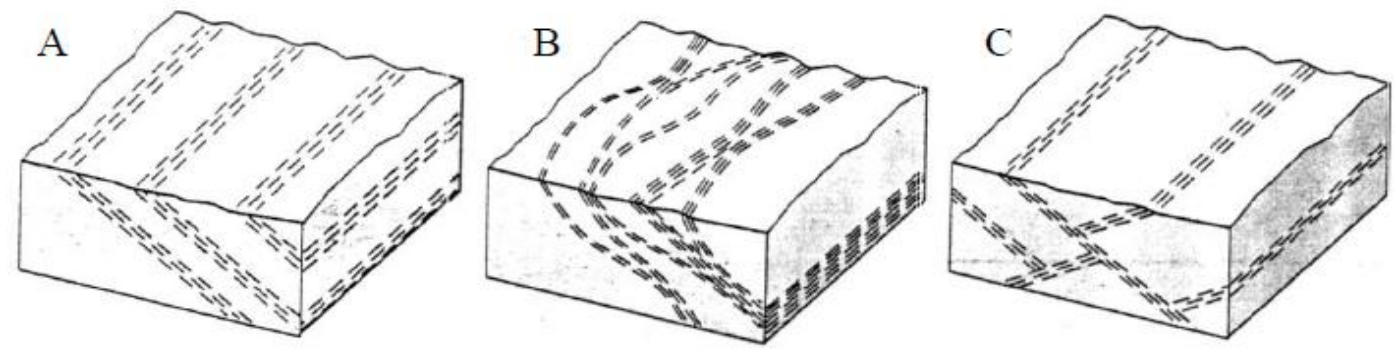

Fig3. Shear zone sets: (A) parallel, (B) anastomosing, and (C) conjugate.
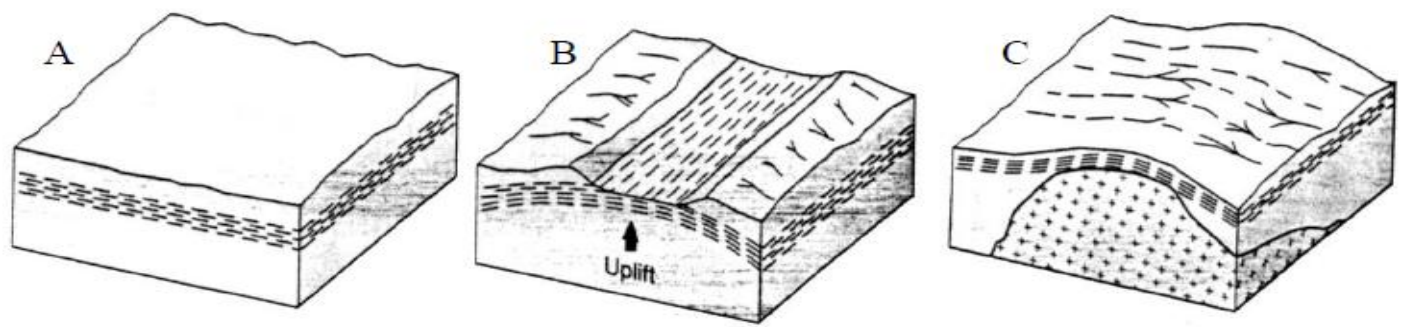

Fig4. Curviplanar shear zones: (A) originally planar shear zone, (B) folding and erosion of same zone to expose a curved shear zone, and $(C)$ shear zone formed with an originally curviplanar geometry.

\subsection{Offset and deflection of markers}

In keeping with fault terminology, there are strike-slip, normal, low-angle normal, reverse, thrust, and oblique-slip shear zones. Strike-slip shear zones may be right-handed (dextral) or left-handed (sinistral) (Figs. 5A \& 9B). Normal-slip shear zones are marked by hanging wall displacement downward relative to the footwall (Fig. 5C). Reverse- and thrust-slip shear zones are marked by hanging wall displacement upward relative to the footwall (Fig. 5D). Oblique shear zones have components of both strike-slip and dip-slip (Woodcock and Fischer, 2002). Another way of describing the sense of shear on subhorizontal or variably dipping shear zones is by specifying which way the hanging wall moved, such as "top to the west" (Fig. 5E). For vertical shear zones with a dipslip component of motion, use phrases such as "west-side up" (Fig. 5F) or "northeast-side down" to convey the sense of shear (Dennis and Secor, 2001).
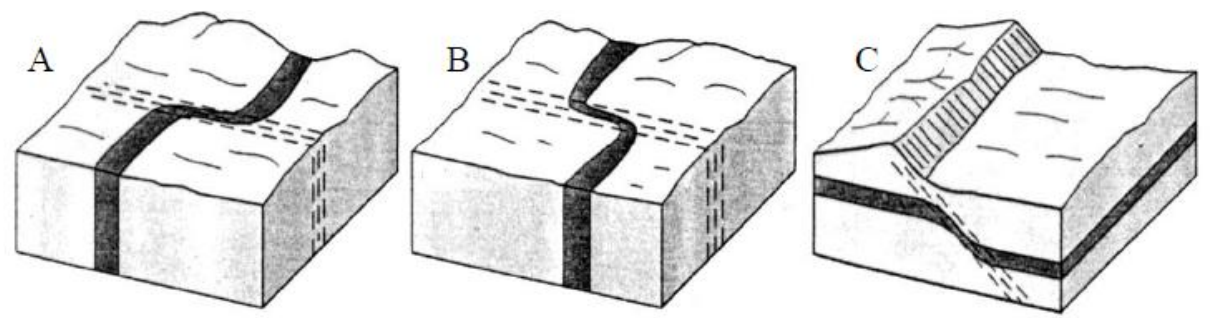

$\mathrm{D}$
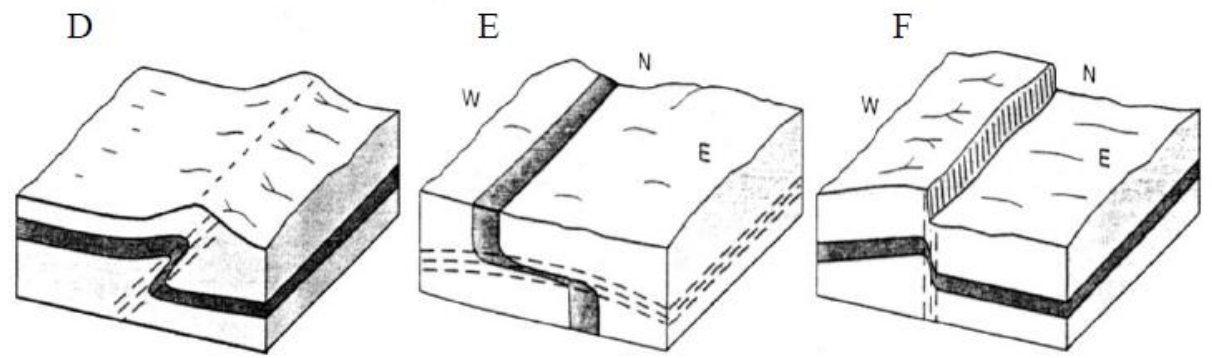

Fig5. Deflection and offset across shear zones: (A) right-handed or dexteral, (B) left-handed or sinistral, (C) normal, $(D)$ reverse, $(E)$ top to the west, and $(F)$ west side up. 


\subsection{Plate Tectonic Settings of Shear Zone}

Shear zones form in a wide variety of tectonic settings (Fig. 6), including plate boundaries of all types. They are undoubtedly forming at depth today in any region with abundant earthquakes or other manifestation of active deformation. Shear zones are present along seismically active strike-slip zones, such as the San Andreas fault of California, the Alpine fault of New Zealand, and the numerous strikeslip faults that dissect China and Tibet north of the India-Asia continental collision. Sites of past extreme extension are represented by shear zones in metamorphic core complexes of western North America and the Aegean (Fig. 7), and by the south Tibetan detachment, which has aided in unroofing the high grade metamorphic rocks of the Himalaya.

\subsection{Types of Shear Zones}

Shear zones were subdivided into four general types, based on the characteristic type of deformation (Davis and Reynolds, 1996): 1- A brittle shear zone contains fractures and other features formed by brittle deformation mechanisms. 2- A ductile shear zone displays structure, such as foliation and lineation, that have a metamorphic aspect and record shearing by ductile flow. 3- Semibrittle shear zones include en echelon veins and stylolites, and involve mechanisms such as pressure solution and cataclastic flow. 4- Brittle-ductile shear zones, which show evidence for both brittle and ductile deformation, form where conditions during shearing either were intermediate between brittle and ductile or change from ductile to brittle or from brittle to ductile.
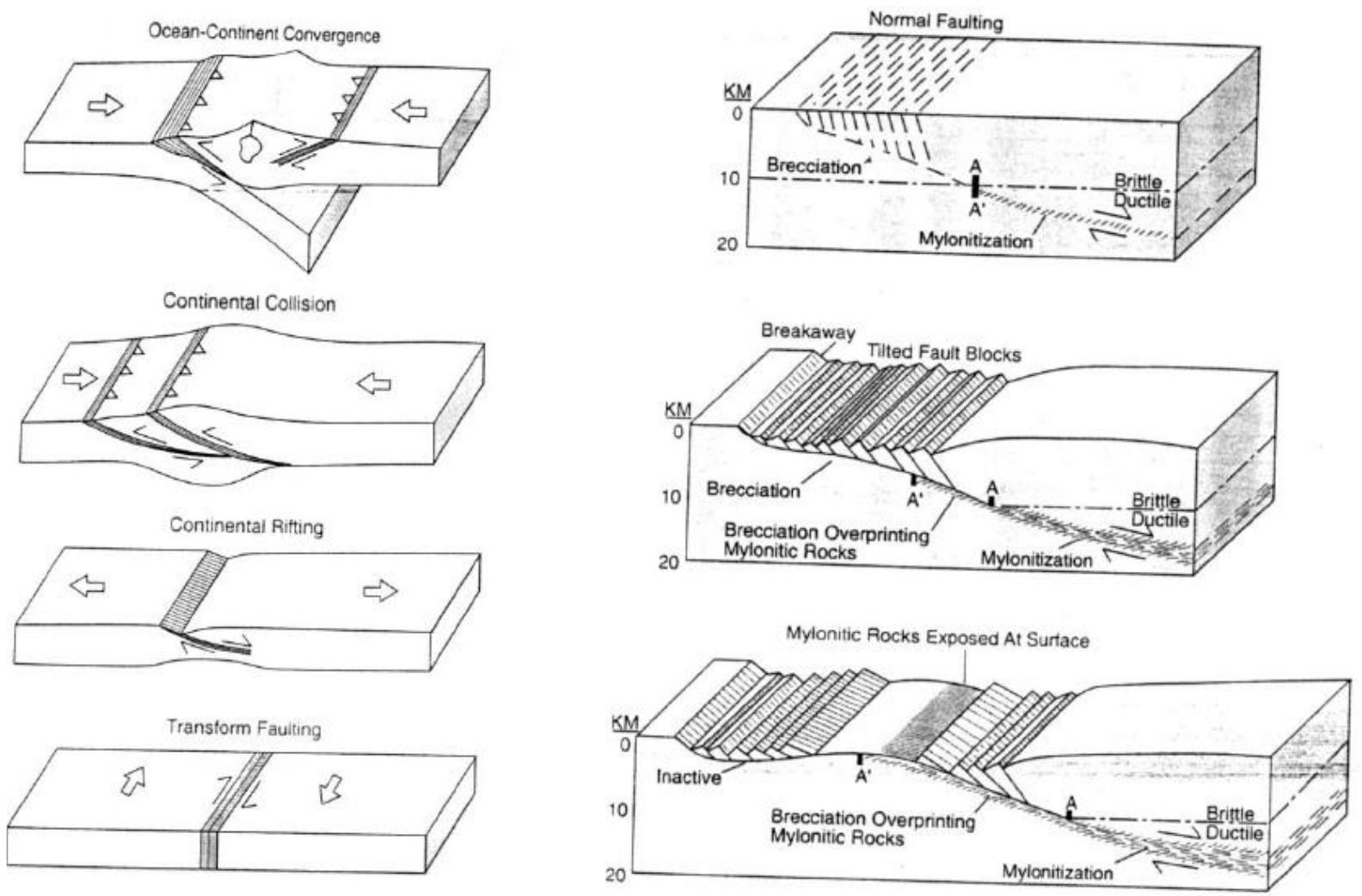

Fig6. Plate tectonic settings of some shear zone.

Fig7. Schematic evolution of a low-angle shear zone with both ductile and brittle segments. Normal displacement along the shear zone progressively unroofs footwall rocks, causing early ductile fabrics to be overprinted by brittle ones as the rocks are isostatically uplifted and cooled. This is one model for the origin of metamorphic core complexes (after Davis, 2000).

\subsubsection{Brittle Shear Zones}

Brittle shear zones form in the shallow parts of the crust, generally within 5-10 km of the earth's surface, where deformation is dominated by brittle mechanisms, such as fracturing and faulting. Accordingly, shear zones formed in this environment are characterized by closely spaced faults, numerous joints and shear fractures, and brecciation. Brittle shear zones are in effect fault zones, and they are marked by fault gouge and other rocks of the breccia series (megabreccia, breccia and 
microbreccia). The dominance of faulting and fracturing in brittle shear zones results in abrupt, sidcontinuous margins that truncate and offset markers. Closely spaced faults define brittle shear zones composed of numerous discrete fault surfaces (Fig. 8) and a chaotic assemblage of strongly fractured and brittely disrupted rocks (Choukroune et al., 1987).

\subsubsection{Ductile Shear Zones}

Ductile shear zones are formed by shearing under ductile conditions, generally in the middle to lower crust and in the asthenosphere. For the most common crustal rocks (e.g. granite), brittle deformation at shallow crustal levels gives way downward into ductile deformation at the brittle-ductile transition.

Most ductile shear zones form under metamorphic conditions, and the resulting sheared rocks are metamorphic in character, typically prossessing foliation and metamorphic minerals. Rocks within a ductile shear zone may be so changed by the intense shear, by metamorphism, and by fluids passing through the shear zone that it becomes very difficult, if not impossible, to decipher the original rockthe protolith (Fig. 9). More commonly, the deformed rocks are assigned to the important family metamorphic tectonites called mylonitic rocks (Ernst, 1999).

\subsubsection{Semibrittle Shear Zones}

Although semibrittle shear zones dominated by brittle deformation mechanisms like fracturing and cataclastic flow, they contain some ductile aspects as well (Fig. 10). A common example of a semibrittle shear zone is a zone of en echelon veins or en echelon joints (Fig. 10A). Deformation along the zone is accommodated by brittle mode fracture, no filled by veins, and by distributed deformation between the veins. Another common example is a zone of en echelon stylolites, formed by pressure solution (Fig. 10B). Some shear zones contain both veins and stylolites, so arranged that the shorteing direction for the stylolites is approximately perpendicular to the extension direction indicated by the veins. Shear zones defined by en echelon folds (Fig. 10C) can be either semibrittle or ductile, depending on the conditions under which they form and on the character of associated structures. Some zones of en echelon folds are formed at greater depths, where trully ductile prevail, but such environments more commonly favor the formation of classic ductile shear zones composed of mylonitic rocks (Gash, 2001).

\subsubsection{Brittle-Ductile Shear Zones}

Brittle-ductile shear zones contain evidence of deformation by both brittle and ductile mechanisms and come in many flavors. Many brittle-ductile shear zones contain boundins, rock fragments and prophyroclasts of the more brittle minerals and rock types.
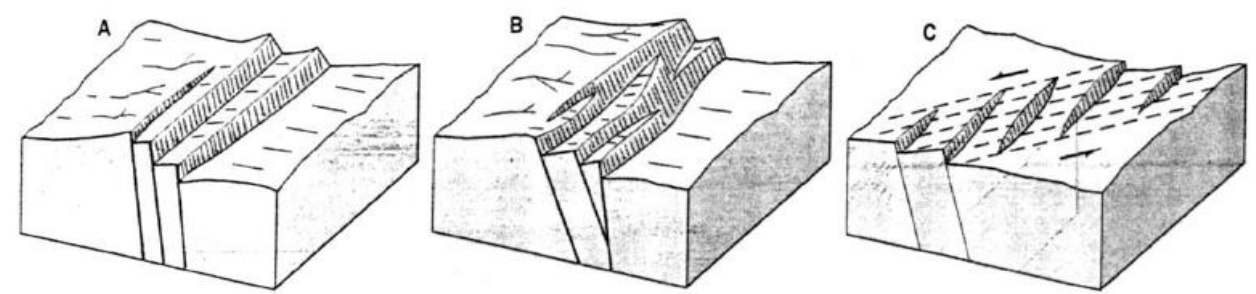

Fig8. Sets of brittle shear zones (faults and fault zones): (A) parallel, (B) anastomosing, and (C) en echelon.
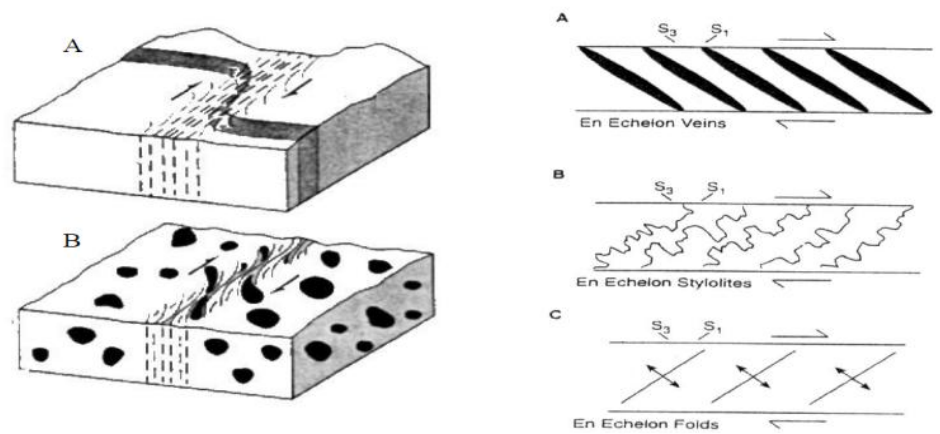

Fig9. Ductile shear zones : (A) marker offset by continuous, dextral shear zone, $(B)$ shear zone cutting plutonic rocks with inclusions and isotropic initial fabric.
Fig10. Semibrittle shear zones: (A) en echelon extension veins, $(B)$ en echelon stylolites, and $(C)$ en echelon folds, $S_{1}$ is the axis of maximum instantaneous stretching, and $S_{3}$ is the axis of maximum intstataneous shortening. 
Brittle-ductile shear zones form when (a) the physical conditions permit brittle and ductile deformation to occur at the same time (Fig. 11A), (b) different parts of a rock have different mechanical properties (Fig. 11B), (c) a shear zone "strain hardness", (d) a short-term change in physical conditions, such as strain rate, causes the rock to switch from ductile to brittle mechanisms or vice versa, (e) physical conditions change systemically during deformation, or (f) as shear zone is reactivated under physical consitions different from those in which the shear zone originally formed. In many cases, the brittleductile character of a shear zone indicates either that physical conditions systematically changed during deformation or that the shear zone formed under one set of conditions and was later reactivated under much different conditions. When conditions change from ductile to brittle, brittle structures, such as fractures, will overprint an earlier ductile fabric in the shear zone (Fig. 12A), a shear zone formed during a change from brittle to ductile conditions, because early, brittle structures may be totally overprinted and "healed" by later ductile fabric and metamorphic minerals (Fig. 12B).

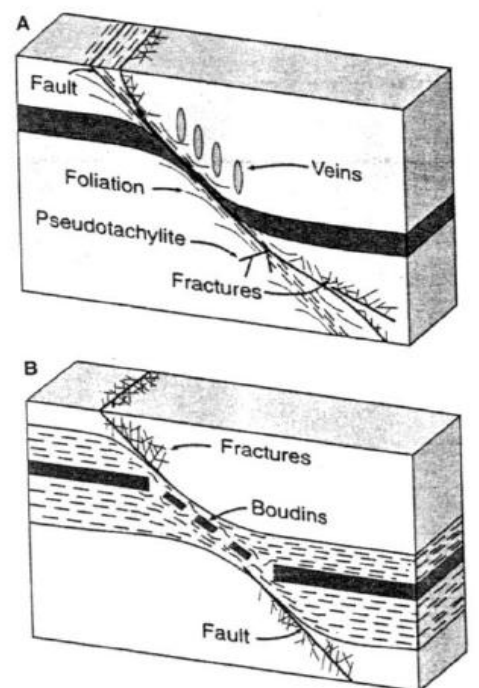

Fig11. Brittle-ductile shear zones. (A) Formed by intermediate (brittle-ductile) conditions, in part due to variations in strain rate and fluid pressure. (B) formed in interlayered rocks with differing rheologies \& responses to deformation (Hanmer \& Passchier, 2000).

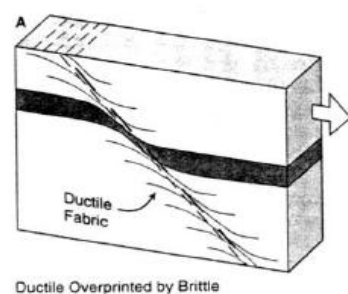

Ductile Overprinted by Brittle
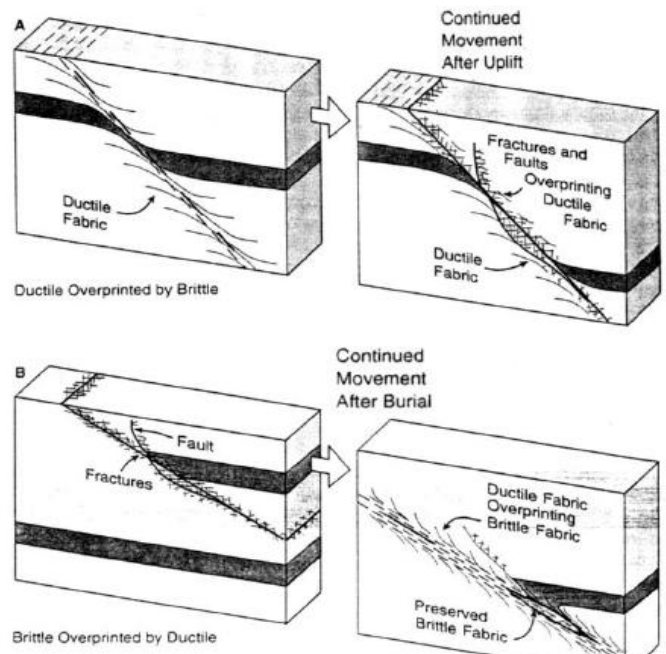

Continued Movement Atter Burial

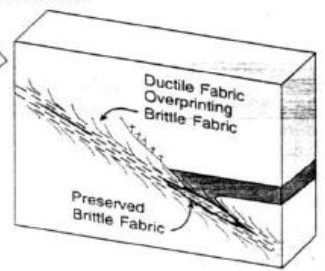

Fig12. Brittle-ductile shear zones formed by a change in physical conditions during shearing. (A) Ductile structures overprinted by brittle ones. (B) Brittle surctures overprinted and largely obliterated by a ductile overprint as rocks are buried (Hanmer \& Passchier, 2000).

\section{VEIN-TyPE URANIUM DEPOSITS RELATED TO SHEAR ZoNES}

\subsection{Definition}

Much of the world's currently mineable uranium is found in vein-like deposits of uncertain origin. They consist of three general types of unequal importance. Most important are unconformity-related deposits and vein-like deposits in metamorphic rocks. Least important and probably of different origin are vein-like deposits in sedimentary rocks. The origin of all three types is a matter of much conjecture. Major unsolved genetic questions are the source of the uranium and its mode of transport, the source of the mineralizing solutions, the nature and role of reductants and the control exerted on uranium deposition by structural and lithologic features of the host rocks. Unconformity-related deposits and vein-like deposits in metamorphics commonly occur in brecciated and foliated metamorphic rocks in stable Precambrian Shield areas, whereas vein-like deposits in sedimentary rocks are found only in strata of Palaeozoic and Mesozoic age (Orphan mine, USA). Deposits of all three types are associated with faults and/or shear zones, but unconformity-related deposits are also closely associated with major regional unconformities where coarse terrestrial clastics overlie metamorphosed basement rocks (Wheathey et al., 1999). Vein deposits consist of uranium mineralization in lenses or sheets or disseminations filling joints, fissures, breccias and stockworks in deformed and fractured rocks. Principal uranium phases are pitchblende, uraninite and coffinite. Uranium may forms monometallic mineralization or polymetallic mineralizations. Associated metals include $\mathrm{Co}, \mathrm{Ni}, \mathrm{Bi}, \mathrm{Ag}, \mathrm{Cu}, \mathrm{Pb}, \mathrm{Zn}, \mathrm{Au}, \mathrm{Mo}$, and/or $\mathrm{Fe}$ in form of sulfides, arsenides or sulfarsenides (Yadava, 1995 and Krishna et al., 1999). 
Veins are deposited by hydrothermal fluids moving along fractures. They are classified as dilative or replacive and are described according to their thickness and extent, their shape, the minerals in them, and the textural and structural arrangements of these minerals. Important structural details are breccia bodies, folds, faults, stylolites and reopened (multiple) vein fillings. Age relations are determined at places where veins cross or where their alteration envelopes overlap. Strikes and dips taken over large areas may help in classifying veins by age and perhaps point to the causes of fracturing. Unless alteration becomes pervasive in veined rock bodies, individual veins are typically enveloped in symmetrical zones of wall-rock alteration. These zones may be uniform and single or may be composite. Composite zones must be studied carefully to determine whether or not the different parts developed simultaneously or in an age sequence. Simultaneous composite zoning, which is probably the most common type, was first proven at Butte, Montana, where an initial phase of high-temperature potassic alteration was followed by a protracted period of hydrothermal alteration during which large numbers of veins that were opened at various times were all enveloped by the same kinds of composite zones (Meyer and Hemley, 1967).

Two principal subtype are recognized, veins spatially and genetically (a) related to granites and (b) veins not related to granites (Table 1).

Table1. Classification of Vein-Type Uranium Deposits Related to Shear Zones in the World (by G.M. Saleh).

\begin{tabular}{|c|c|c|c|c|c|c|}
\hline \multicolumn{2}{|r|}{ Subtype } & Regional geology & $\begin{array}{l}\text { Ore and associated } \\
\text { minerals }\end{array}$ & Alteration processes & Locality of shear zones & Remarks \\
\hline \multirow{4}{*}{ 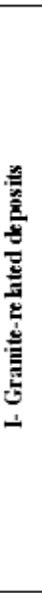 } & a-Intragranitic & $\begin{array}{l}\text { Two-nica granites, } \\
\text { lamprophyre, pegmatite, } \\
\text { aplite and micro-granite } \\
\text { dikes }\end{array}$ & $\begin{array}{l}\text { Pitchblende, coffinite and } \\
\text { associated with pyrite, } \\
\text { marcasite, fluorite, galena }\end{array}$ & $\begin{array}{l}\text { Muscovitization, } \\
\text { chloritization, } \\
\text { pyritization, } \\
\text { hematitization and } \\
\text { adularia formation }\end{array}$ & $\begin{array}{l}\text { Intragranitic, France } \\
\text { (Limousin type) stockwork } \\
\text { shear zone (NW-SE) }\end{array}$ & $\begin{array}{l}\text { 1- Veins or stringers of pitchblende } \\
\text { occur in simple linear } \\
\text { configuration or breccias. } \\
2 \text { - Reserves range between } 0.1 \text { - } \\
4096 \mathrm{U}_{2} \mathrm{O}_{2}\end{array}$ \\
\hline & $\begin{array}{l}\text { b- Perigranitic } \\
\text { Monometallic veins }\end{array}$ & $\begin{array}{l}\text { Wealdy metamorphosed } \\
\text { upper Proterozoic schists, } \\
\text { Cambrian conglomerates } \\
\text { and sandstones folded. Dikes } \\
\text { including aplitic granite, } \\
\text { aplite and lamprophrre }\end{array}$ & $\begin{array}{l}\text { Pitchblende, coffinite, } \\
\text { uranium-anthraxolite sulfides } \\
\text { of } \mathrm{Fe}, \mathrm{Pb}, \mathrm{Zn}, \mathrm{Cu} \text {, which are } \\
\text { present in minor to trace } \\
\text { amounts }\end{array}$ & $\begin{array}{l}\text { Sericitization, } \\
\text { chloritization, } \\
\text { carbonatitization, } \\
\text { hydrohematitization and } \\
\text { illitization }\end{array}$ & $\begin{array}{l}\text { Bohemian pluton, Pribram, } \\
\text { CSFR shear zones trending } \\
\text { NE-SW, about } 25 \mathrm{~lm} \text { long } \\
\text { and } 1 \text { to } 2 \mathrm{~km} \text { wide }\end{array}$ & $\begin{array}{l}\text { 1- U and gangue minerals form } \\
\text { stringers, coatings, reniform } \\
\text { accretions and pods. } \\
\text { 2- Ore shoots usually occupy } \\
\text { between } 0.1-10 \% \mathrm{U}_{2} \mathrm{O}_{\mathrm{n}}\end{array}$ \\
\hline & $\begin{array}{l}\text { c- Perigranitic } \\
\text { polymetallic veins }\end{array}$ & $\begin{array}{l}\text { Graphitic mica schists, } \\
\text { phyllites, altered } \\
\text { leucogranite and hornfels. } \\
\text { Magmatic dykes occurs, } \\
\text { including aplitic granite, } \\
\text { pegmatite and lamprophyre }\end{array}$ & $\begin{array}{l}\text { Pitchblende and coffinite } \\
\text { sulfides and sulfarsemides of } \\
\mathrm{Ag}, \mathrm{Co}, \mathrm{Ni} \text { and } \mathrm{Bi} \text {. }\end{array}$ & $\begin{array}{l}\text { Hematitization of pyrite, } \\
\text { dolomitization of calcite } \\
\text { and carbonatitization }\end{array}$ & $\begin{array}{l}\text { - Erzgebrige type, CSFR } \\
\text { brittle shear zones trending } \\
\text { NNW-SSE. } \\
\text { - Argentina shear zone } \\
\text { (continuous) trending } \\
\text { NWW-SSE. }\end{array}$ & $\begin{array}{l}\text { 1- Simple veins are composed of } \\
\text { pitchblende, carbonate and gouge } \\
\text { with mylonitized rocls. } \\
2 \text { - Complex veins are composed of } \\
\text { pitchblende and quartz-sulfide } \\
\text { assemblages. } \\
\text { 3- Grades range }<0.1 \% \text { to several } \\
\text { percent } \mathrm{U}_{3} \mathrm{O}_{3}\end{array}$ \\
\hline & $\begin{array}{l}\text { d-Perigranitic In } \\
\text { contact- } \\
\text { metamorphics }\end{array}$ & $\begin{array}{l}\text { Pelitic-psammitic sediments } \\
\text { but is contact- } \\
\text { metamorphosed into hornfels } \\
\text { and granites dykes of } \\
\text { microgranite and } \\
\text { lamprophyre }\end{array}$ & $\begin{array}{l}\text { Pitchblende, autunite and } \\
\text { coffinite, pyrite, chalcopyrite, } \\
\text { galena, fluorite and adularia. }\end{array}$ & $\begin{array}{l}\text { Hematitization, adularia, } \\
\text { sericitization, } \\
\text { argillitization, } \\
\text { silicification }\end{array}$ & $\begin{array}{l}\text { Iberian type shear zone } \\
\text { approximately } 2 \mathrm{~km} \text {. Faults } \\
\text { displace the granite contact, } \\
\text { Portugal-Spain, Oldo in } \\
\text { Gabon, Southwestern } \\
\text { Madagascar \& Cameron } \\
\text { shear (ductile) zone. }\end{array}$ & $\begin{array}{l}\text { 1-U minerals occur as } \\
\text { disseminations mainly in the } \\
\text { oxidized zone with intensely } \\
\text { fractured slivers. } \\
2 \text { - The minerals imprergnate and } \\
\text { coat fracture and schistosity } \\
\text { surfaces. . - Average grade low; } \\
\text { about } 0.1 \mathrm{U}, 0 \text {, or less }\end{array}$ \\
\hline \multirow{2}{*}{ 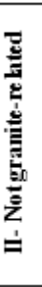 } & $\begin{array}{l}\text { a- In metamorphic } \\
\text { rocks }\end{array}$ & $\begin{array}{l}\text { Mafic metasediments, } \\
\text { metamorphosed to } \\
\text { amphibolite grade facies, } \\
\text { with large tensional } \\
\text { structures (Illinois and } \\
\text { Rogers faults). }\end{array}$ & $\begin{array}{l}\text { Uraniunite, pitchblende, } \\
\text { gummite, coffinite and in } \\
\text { oxidized zones hexavalent U } \\
\text { minerals. Sulfides, arsenides, } \\
\text { fluorite, barite, native bismuth } \\
\text { \& native gold and calcite. }\end{array}$ & $\begin{array}{l}\text { Carbonatiozation, } \\
\text { pyritization, sericitization, } \\
\text { bematitization, illitization } \\
\text { and l-feldspathization } \\
\text { (adularia) }\end{array}$ & $\begin{array}{l}\text { - Schwartzwalder, Colorado } \\
\text { shear zones, trending NNWW } \\
\text {-SSE (Illionis fault, USA). } \\
\text { - Shear zone deposits in } \\
\text { metamorphic : a- } \\
\text { Saskatchewan in Canada, b- } \\
\text { Echo-Bay in Canada, c-East } \\
\text { Bavaria in Germany. }\end{array}$ & $\begin{array}{l}\text { 1- U and gangue minerals form } \\
\text { veinlets and vein larger tensional } \\
\text { streuctures. } \\
2 \text { - Grades ranging form } 0.2 \text { to } \\
0.49 . \mathrm{U}_{3} \mathrm{O}_{3} \text {. } \\
\text { 3-Mineralization includes three } \\
\text { stages. Stage II is the principal } \mathrm{U} \\
\text { phase. }\end{array}$ \\
\hline & $\begin{array}{l}\text { b-In sediments } \\
\text { (polymetallic) }\end{array}$ & $\begin{array}{l}\text { Host rocls consist of various } \\
\text { sedimentary lithologies. } \\
\text { Siliceous dolomite, dolomitic } \\
\text { and carbonaceous shales. }\end{array}$ & $\begin{array}{l}\text { Uranitie and pitchblende. } \\
\text { Associated minerals may } \\
\text { include } \mathrm{Co} 0-\mathrm{Ni} \text { sulfides and } \\
\text { selenides, sulfides of } \mathrm{Fe}, \mathrm{Cu} \text {, } \\
\mathrm{Mo}_{0}, \mathrm{~Pb}, \mathrm{Zn} \text { and monazite }\end{array}$ & $\begin{array}{l}\text { Mg-metasomatism, } \\
\text { chloritization, } \\
\text { dolomitization and } \\
\text { silicification }\end{array}$ & $\begin{array}{l}\text { - Zaire (Shaba, Katanga) } \\
\text { shear zones trending } \\
\text { between E-WW and NE-SW } \\
\text { - SE England shear } \\
\text { (conjugate) zone }\end{array}$ & $\begin{array}{l}1-\mathrm{U} \text { and gangue minerals occur in } \\
\text { veins, stockworls along bedding } \\
\text { planes, as breccia. } \\
2 \text { - Grades ranging from } 0.1 \text { to }>10 \% \\
\mathrm{U}_{2} \mathrm{O}_{3} \text { and more. }\end{array}$ \\
\hline
\end{tabular}

a) granite-related deposits are associated with highly differentiated peraluminous leucogranites and form veins either within (intragranitic) or around (perigranitic) the intrusion (IAEA, 1986).

- Intragranitic deposits are commonly monometallic and occur either as (a) linear ore bodies in form of distinct veins or stockworks emplaced in fractured granite or (b) disseminations in pipes or chimneys of episyenite, a dequartzified, micaceous vuggy alteration product of granite. Depth extension of intragranitic veins is commonly less than $300 \mathrm{~m}$.

- Perigranitic deposits emplaced in metasediments are either monometallic consisting essentially of pitchblende and gangue minerals or polymetallic containing both $\mathrm{U}, \mathrm{Co}, \mathrm{Ni}, \mathrm{Bi}, \mathrm{Au}$ and $\mathrm{Ag}$ minerals in economic quantities. Both monometallic and polymetallic veins can persist as much as $2000 \mathrm{~m}$ deep. Perigranitic deposits emplaced in the contact-metamorphic aureole of the intrusion have monometallic mineralization in form of veinlets and disseminations in intensely fractured hornfels, speckled andalusite-cordierite schist and similar rocks up to approximately $2 \mathrm{~km}$ wide around the granite.

b) Not granite-related deposits are similar in mineral composition and wall rock alteration to perigranitic veins in metasediments but do not reveal any apparent link to granitic intrusions. 


\subsection{Types of Veinlike-Fructure System}

\subsubsection{Seamlike (Beaverlodge-Jabiluka) Type}

This type is characterized by lense- to seamlike orebodies which follow more or less strata concordant folded metasediments (Fig. 13). They extend to depths of $1.000 \mathrm{~m}$ and more. Besides the seamlike mineralization, mineable ore is found, especially in the Beaverlodge mines, Canada, in breccia zones adjacent to the strata-bound orebodies.

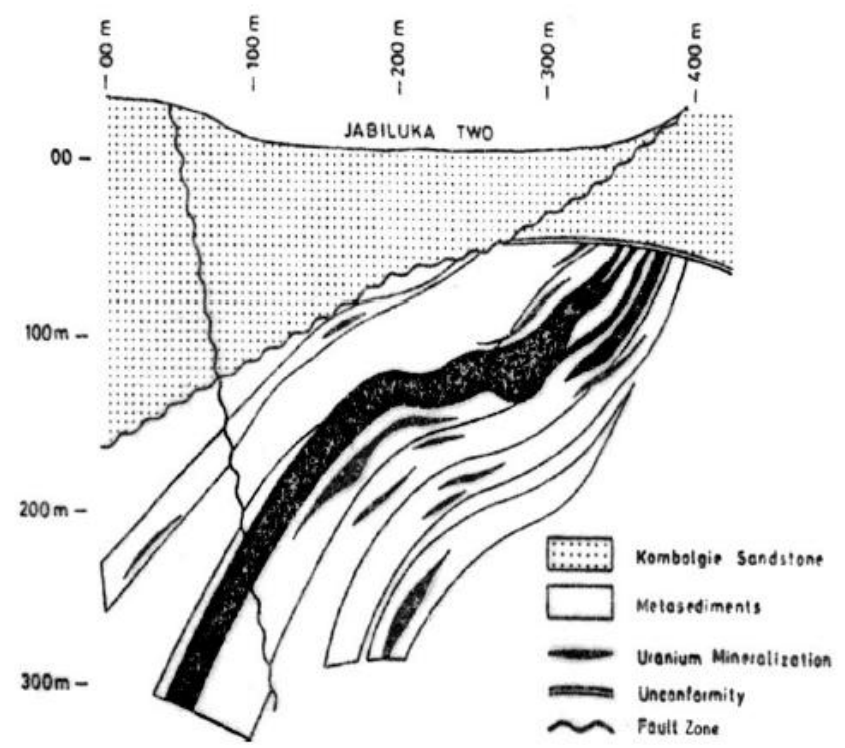

Fig13. Veinlike-type (seamlike type).

The host rocks are graphite-chlorite-sericite-schists, silicifed feldspar rocks, resulting from retrograde metamorphism of metasediments originally metamorphosed into amphibolite to granulite facies. The ore is dominantly monometallic, but locally also polymetallic (e.g. Jabiluka). The main ore minerals are Th-free pitchblende, coffinite and additional alteration minerals such as sooty pitchblende and in zones of oxidation/weathering secondary U-minerals. Gangue include calcite, dolomite, quartz and hematite. The average uranium grades vary between 0.1 and $0.4 \%$ U. Thicknesses range from a few centimeters to several meters (Dahlkamp, 1979 and Beck, 1994).

\subsubsection{Unconformity-(Key Lake) Type}

The deposits of this unconformity type as represented by the Key Lake deposit in Canada, occur in fault-and shear zones along a Middle Proterozoic Paleo-surface weathered into a regolith. They form massive ore bodies (Key Lake) as well as impregnations (Rabbit Lake, Canada; Upper portion of Koongarra and Nabartek, Australia).The host rocks are graphite, chlorite, sericite schists, metaarkoses, carbonatic (dolomitic) quartizites, altered gneisses (Fig. 14). The later retrogradely metamorphosed sediments were originally metamorphosed into the amphibolite-granulite facies.

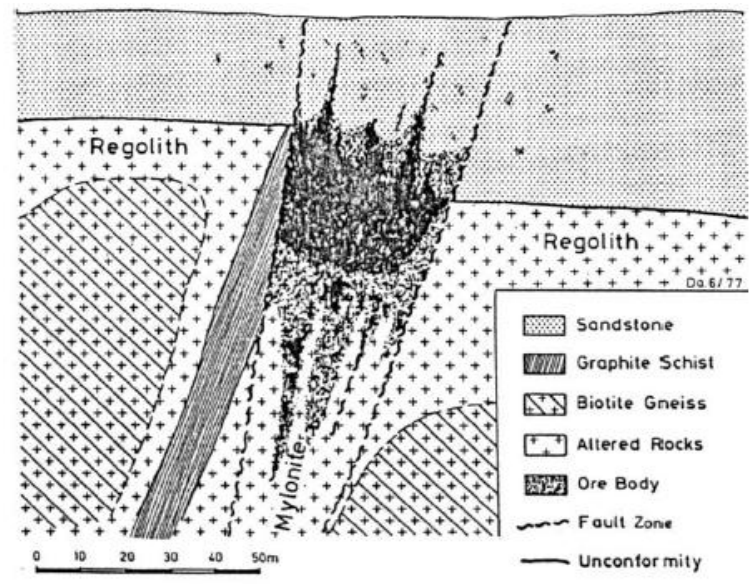

Fig14. Veinlike (Key Lake type). 
The main mineralizations are bound by and concentrated beneath this unconformity but mobilized uranium enters also fractures in the overlying sandstones. The oregrade mineralization is dominantly mono, more rarely polymetallic (Key Lake: uranium and nickel). Main ore mineral is colloidal, thorium-free pitchblende. Alteration minerals are sooty pitchblende and coffinite. Gangue, it consist of quartz and carbonates, occasionally hematite and/or chlorite and kaolinite. Average uranium contents in these deposits vary between 0.1 and $0.4 \%$, in some deposits between 1 and 3\% (Dahlkamp, 1978, Gatzweiler et al., 1997 and McMillian, 1998).

\subsubsection{Granite Endocontact- (Massif Central, France) Type}

This vein like type of deposits, as found especially, but not exclusively in the Massif Central in France is characterized by near-surface (contact) uranium veins and disseminated mineralization in fault and shear zones of intrusive, deuteric granite, named autometasomatic granite and two-mica granite (Fig. 15).

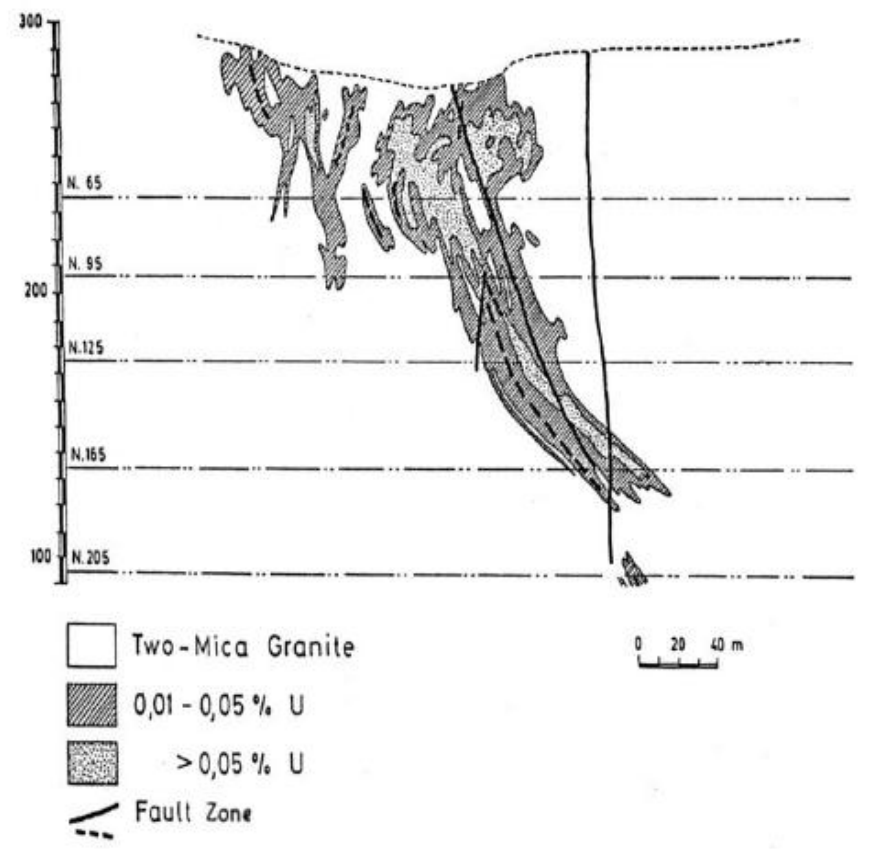

Fig15. Veinlike type (Massif Central, France).

The main ore mineral is colloidal, thorium-free pitchblende. Alteration products are para-pitchblende, neo-pitchblende (sooty pitchblende) and, partly in unusually deep penetrating oxidation zones, colored secondary uranium minerals. Gangue is variably abundant in form of quartz, carbonates and fluorite. Average uranium contents vary between 0.05 and $0.3 \%$. thicknesses of ore zones range from a few centimeters to meters, rarely tens of meters (Cuney, 1978 and Cathelineau, 1981).

\subsection{Classical Vein Deposits}

Two end-member compositional varieties of vein have been recognized: (1) veins with simple mineralogy, with uranium predominantly as pitchblende (2) veins with complex mineralogy that includes $\mathrm{Ag}, \mathrm{Co}, \mathrm{Ni}, \mathrm{Bi}$ and other elements such as $\mathrm{As}, \mathrm{Au}, \mathrm{Se}$ and $\mathrm{Cu}$ chiefly in the form of sulfides, selenides and sulfarsenides (Ruzicha, 1993 and McMillian, 1996).

\subsubsection{Veins with Simple Mineralogy}

\section{$>$ Shear Zones of the Xiazhuang Uranium Deposits in China}

The Xiazhuang ore field is one of the important uranium districts of China from which substantial uranium resources are known. All deposits of this area belong to the hydrothermal vein-within metamorphic rocks, surrounding granites. Uranium mineralization is controlled by structures and favourable lithological units. Faults and shear zones generally have an NE-SW direction (Fig. 16). Principal uranium minerals are pitchblende and coffinite. Associated minerals can include a variety of sulfides, arsenides, ilmenite, fluorite, apatite. The average grade of uranium within these veins ranges from 0.1 to $0.5 \% \mathrm{U}$ and the size of the orebodies varies considerably (Li Tianging, 1986). Several stages of oxidation and reduction affected the host rocks. Alteration processes include pyritization, hematitization, hydromicatization, argillitization of feldspars and silicification. 


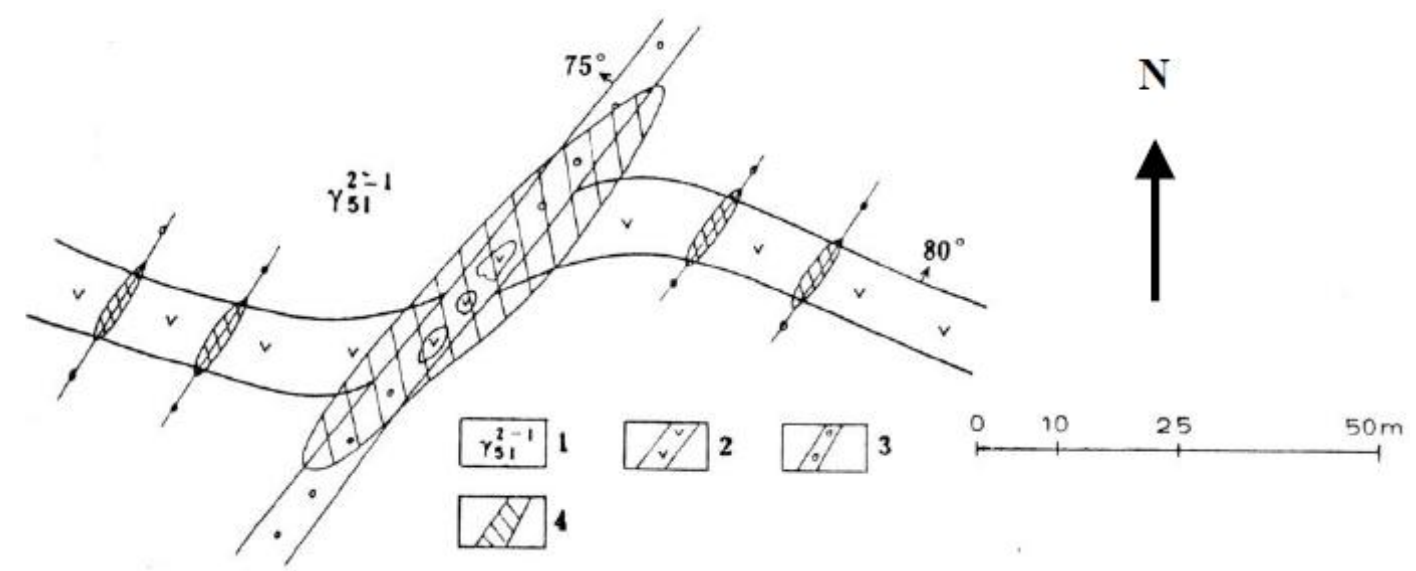

Fig16. Sketch map of Xiazhuang shear zone uranium deposits. 1-Porphyritic biotite granite, 2-Intermediate basic dyke, 3- silicified shear zone, 4-orebody.

\subsubsection{Veins with Complex Mineralogy}

\section{Shear zones of the schwartzwalder uranium deposits in Colorado, USA}

Host rocks include a variety of mafic metasediments often, but not necessarily, metamorphosed to amphibolite grade facies. Schwartzwalder ore is associated with large tensional structures (Illinois and Rogers shear zones) and their branching horsetail fractures that discordantly transect strata (Fig. 17). They contain ore almost exclusively where they cut horizons of garnet-biotite-gneiss (protolith : iron and surface-rich pelitic sediments) and quartizite adjacent to hornblende gneiss (mafic volcanite). Principle uranium minerals are uraninite, pitchblende, coffinite and in oxidized zones hexavalent $U$ minerals. Associated minerals can include a variety of sulfides, aresenides, selenides mostly of $\mathrm{Fe}, \mathrm{Cu}$, $\mathrm{Pb}, \mathrm{Zn}, \mathrm{Mo}$ and trace amounts of $\mathrm{Ag}, \mathrm{Au}, \mathrm{Co}, \mathrm{Ni}, \mathrm{Hg}$ and $\mathrm{Sb}$. Gangue minerals may be carbonates (calcite, dolomite, ankerite), quartz, adularia, fluorite and barite. Fluids migrated along the fracture systems to zones of low hydraulic potential. These fluids contained $\mathrm{CO}_{2}$ and had a metastably large $\mathrm{K} / \mathrm{Na}$ ratio; they altered the gneissic wall rocks to a carbonate-sericite assemblage, adding $\mathrm{K}^{+}$and $\mathrm{CO}_{2}$ and removing $\mathrm{SiO}_{2}$ with little or no change in volume. As the fractures continued to open, $\mathrm{CO}_{2}$ was evolved from the fluids, increasing the $\mathrm{pH}$ and superimposing a hematite adularia alteration assemblage on the earlier alteration.

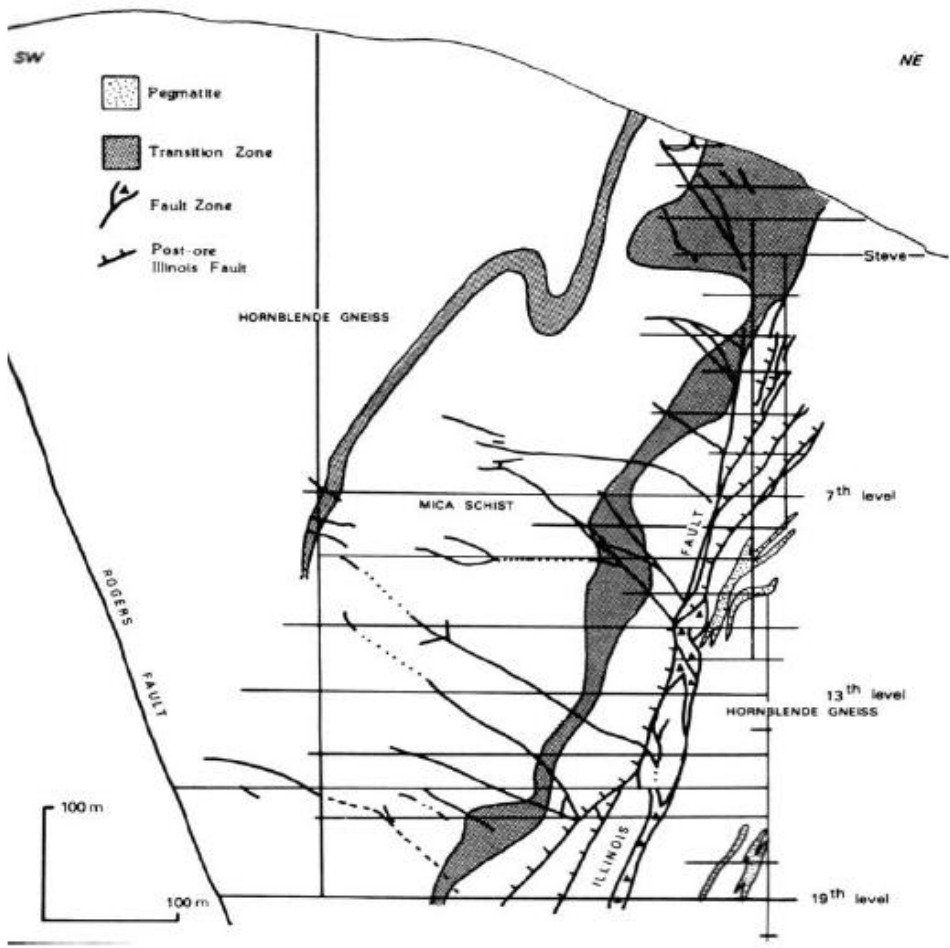

Fig17. Cross section of the Schwartzwalder mine, showing the distribution of shear zones and rock units (after Wallace \& Whelan, 1986). 


\subsection{Shear Zone Uranium Deposits in Metamorphic Rocks}

Vein-type uranium deposits have been placed with deposits of uncertain genesis by Bendix. This type of deposit occurs in structurally controlled sites adjacent to steeply dipping, major shear zone systems (Mathews, 1978). Most of the larger veins are found in metamorphic rocks of Proterozoic age and consist of pitchblende either alone or in association with a variety of sulfides, arsenides and other minerals. Mineralization includes $\mathrm{Co}, \mathrm{Ni}, \mathrm{Cu}, \mathrm{Au}$ and $\mathrm{Ag}$ in the deposits of the Echo By-Eldorado Mines area of the Northwest Territories, Canada. These deposits are commonly strongly influenced by wall-rock lithology adjacent to the vein with carbonaceous, chloritic, and carbonate units being favorable hosts. Hydrothermal alteration of the wall-rocks produces chlorite, hematite, quartz and carbonate minerals. In the fools peak area of the Rawhide Mountains, Arizona, high-grade uranium mineralization is present in veins that are associated with hematite and silicification. The veins discordantly cut mylonitic fabric of Tertiary age. Uranium mineralization is present in small veins in the Harcuvar Mountains to the south where it is accompanied by copper and gold. The mineralization is probably magmatic-hydrothermal due to its spatial and possible genetic relation with microdiorite dykes that intrude amphibolite-grade metamorphic rocks and nearby foliated granites.

Favourable host rocks are carbonaceous slates,chloritized schists and gneisses, graphitic units, metacarbonates and metavolcanics. All these rocks are characterized by retrogressive chloritization that predates uranium mineralization. Hematite haloes are common around ore, and carbonatization and chloritization are also normal features of the deposits. Both monometallic and polymetallic types of deposits are recognized (Badham, 1996 and Bain, 1998). Pitchblende is the principal uranium mineral in both types of deposits, and $\mathrm{Ag}, \mathrm{Au}, \mathrm{Ni}, \mathrm{Cu}, \mathrm{Co}$ form accessory minerals (sulphides and arsenides) in the polymetallic deposits. Minerals assemblages, wall rock alteration types and mineral formation temperatures suggest that these deposits were generated from medium-to low temperature hydrothermal solutions (Ferguson, 1998 and Oliver et al., 1999).

\subsubsection{Shear Zone Uranium Deposits in Northern Saskatchewan, Canada}

The northeren Saskatchewan area is characterized by monometallic vein-like uranium deposits in metamorphic rocks (Sassano et al., 1972) Underlying this metamorphosed and granitized gneiss of the lower Huronian Tazin Grou. The gneiss is unconformably overlain by continental red beds of the Middle Huronian Martin Formation. Pitchblende and calcite occur in veins multiple-vein systems in the Tazin, and some pitchblende occurs in the overlying Martin. Uranium-bearing veins have a strike length of more than $4500 \mathrm{~m}$ and they extend to a depth of more than $1645 \mathrm{~m}$. The pitchblende occurs as vein fillings in shears, fractures and brecciated zones within $100 \mathrm{~m}$ of the St. Louis Fault. It is also disseminated in rocks adjacent to the veins. Initial pitchblende deposits (1780 m.y age) was followed by a thermal event that remobilized and redeposited the uranium about 1140 m.y. age.

\subsubsection{Shear Zone Uranium Deposits in Echo Bay-Eldorado Mine, Canada}

The Echo Bay and Eldorado uranium-silver mines in northwest Territories Canada are polymetallic vein-like deposits in metamorphic rocks (Robinson and Ohmoto, 1990). The two mines are in a vein system containing $\mathrm{U}, \mathrm{Ag}, \mathrm{Au}, \mathrm{Ni}$ and $\mathrm{Cu}$. The veins occur in roof pendants of Aphebian sedimentary and volcanic rocks (Echo Bay Group) within a Hudsonian granitic intrusive. The margins of the pendants were thermally metamorphosed, but the centres are little metamorphosed. Mineralization occurs in green and red banded andesitic tuffs in the pendant centres. Ore occurs in three steeply dipping veins that average $0.5 \mathrm{~m}$ in thickness, $1500 \mathrm{~m}$ in length and more than $400 \mathrm{~m}$ in depth. Shear zones contain pitchblende, coffinite, gummite, native silver, native bismuth with small amounts of base-metal sulphides, fluorite, galena, adularia and Co-Ni arsenides. Shear zones are surrounded by a halo of feldspatization, choritization, carbonatization and pyritization (Table 1).

\subsection{Structural Setting of Shear Zones and Associated Uranium Deposits}

The structural modes of deposit and orebodies occurrence are characterized by folded and fractured structures which, according to the scale of distribution and significant influence, can be subdivided into:

1. Regional structures which determine the localization of ore-bearing regions or belts.

2. Structures which determine the localization of ore fields and deposits.

3. Structures which control the localization of individual orebodies. 
4. Structures which determine the distribution of mineralization within the orebodies.

The tectonic structures of different deposits and orebodies have different influences on the process of ore formation and, consequently, on the regularity of a deposits distribution in space (Table 2).

Table2. Ore control by tectonic shear-sense structures (after Belevtsev, 1980).

\begin{tabular}{|l|l|}
\hline Structures & Characteristics \\
\hline $\begin{array}{l}\text { 1- Regional structures determining } \\
\text { the localization of mineral regions } \\
\text { and belts. }\end{array}$ & $\begin{array}{l}\text { During the geosynclinal cycle large folded-fracture zones were } \\
\text { initiated and developed in synclines. Abyssal faulting began and } \\
\text { developed during the final phases of the geosynclinal period. }\end{array}$ \\
\hline $\begin{array}{l}\text { 2- Structures enclosing ore fields } \\
\text { and deposits. }\end{array}$ & $\begin{array}{l}\text { Compressed, steeply dipping synclines complicated by transverse } \\
\text { folds, longitudinal and intersecting faults. Open, steeply dipping } \\
\text { synclines were complicated by faults. Large shear zones are areas of } \\
\text { conjugation with stratified metamorphic rocks. Shear zones are } \\
\text { marked by single fissures or series of conjugal shear fissures. }\end{array}$ \\
\hline $\begin{array}{l}\text { 3- Structures controling the } \\
\text { localization of separate orebodies. }\end{array}$ & $\begin{array}{l}\text { Bends complicated the limbs of syncldines. Fractures developed on } \\
\text { the limbs and in areas of closure. Areas of conjugal shearing and } \\
\text { feathered fissuring developed. Single fractures are curved. Fissured } \\
\text { blocks are isolated between contiguous fractures }\end{array}$ \\
\hline $\begin{array}{l}\text { 4- Structures determining the } \\
\text { localization and distribution of } \\
\text { orebodies. }\end{array}$ & $\begin{array}{l}\text { Shear zones were accompanied by microfolding. The development of } \\
\text { small joints increased porosity. Brecciation, cataclasis and myloni- } \\
\text { tization developed }\end{array}$ \\
\hline
\end{tabular}

\subsubsection{Structures controlling the localization of separate orebodies}

Shear zones are related to intrageosynclinal structures; they are developed along the edges of marginal troughs and inner geosynclinal areas. The faults are contained within a series of submeridional zones of fracturing, brecciation, and cataclasis. Shear zones are also featured in the development of separate areas of alkaline and carbonate metasomatism. The pegmatite veins occurred earliest in the shear zones and were followed by the formation of albitites and albitized rocks. The albitized rocks, in many cases, were later brecciated and broken down. Uranium minerals and post-ore-stage minerals were superimposed on the albitized rocks. Shear zones are situated within transition areas where migmatites and granites are altered to gneisses. Consequently, faults with hydrothermal alterations are situated on the edges of thermal domes. Thermal domes represent the maximum to which a rock can be granitized (Fig. 18). The renovating of faults and hydrothermal alteration are confined to a postgranitized area.

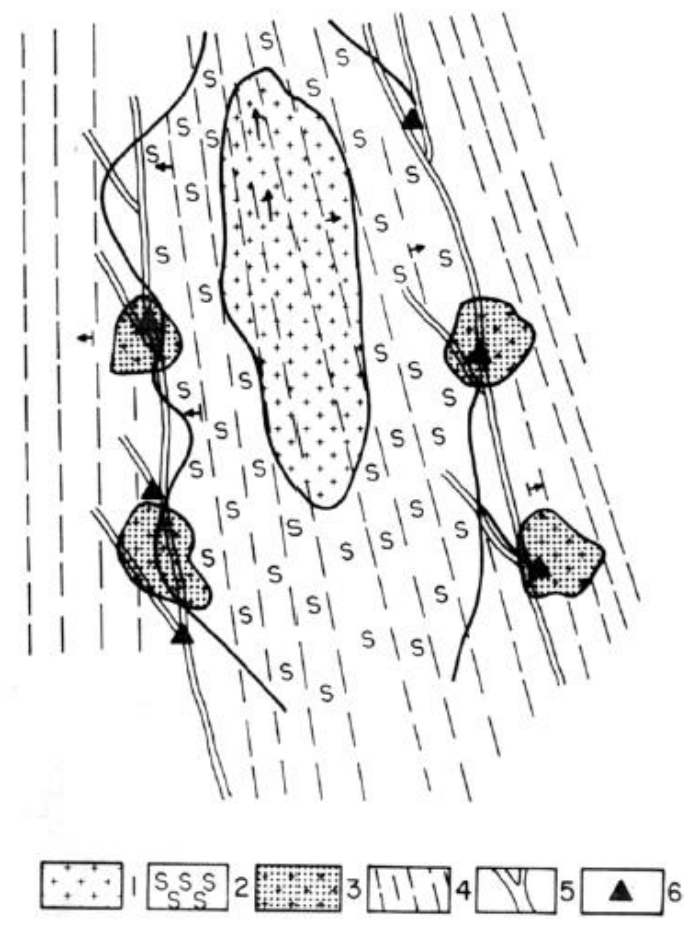

Fig18. Schematic representation of the thermal dome and distribution of deposits, Russian. 1-granite; 2-migmatite; 3-albitized granite; 4-amphiboittic facies rocks; 5-shear zones; 6- ore deposits (after Belevtsev, 1980). 
The fracture structures controlling the localization of separate orebodies are:

1. Compressed, steeply dipping synclinal folds (broken or refolded) by transverse and longitudinal bends.

2. Open, steeply dipping synclinal folds complicated by longitudinal and transverse faults.

3. Large shear zones with stratified layers of metamorphic rocks broken or crushed by numerous small faults in areas of conjugation.

4. Single fissures or a series of conjugated shear fissures caused by fault zones.

5. Intersections of shear zones trending in different directions.

6. Areas of bedding in fracture systems or individual faults.

\section{URANiUM MineRALIZATION IN THE EGYPTIAN SHEAR ZONES}

\subsection{Firstly in Granitic Rocks}

\subsubsection{El-Missikat - El Erediya Area}

The geology of El Erediya area has been extensively studied by many authors including El Tahir (1985), Abu-Deif (1985, 1992), Hussein et al. (1986), El Kassas and Bakhit (1989), El-Kammar et al. (1997), Osmond et al. (1999), and Abu Deif et al. (2001). The oldest rock units are ophiolitic rocks followed by metavolcanic rocks, then an early magmatic phase, which is represented by diorites and granodiorites, followed by a later magmatic phase of undeformed granites, felsites, and finally, a swarm of mineralized jasperoid veins and post granitic dykes (Fig. 19).. Uranium mineralization is associated with the hydrothermally altered parts of the El Erediya granite and localized within several shear and fractured zones that are filled with jasperoid veins. Chemical analyses of eight mineralized samples from the jasperoid veins indicate that $U$ ranges from 200 to $600 \mathrm{ppm}$ with an average of 462 ppm, whereas Th ranges from 13 to $16 \mathrm{ppm}$ with an average of $15 \mathrm{ppm}$ (El-Kammar et al. 1997). The mineralized shear zones are controlled by $\mathrm{N}-\mathrm{S}$ to NE-SW and NW-SE fractures with infilling jasperoid veins. Massive and disseminated pitchblende, as well as other secondary uranium minerals such as uranophane, kasolite, and renardite were detected in shear zone (Hussein et al. 1986). Based upon the $\mathrm{U}-\mathrm{Pb}$ isochron method, the estimated age of the pitchblende varies from 130 to $160 \mathrm{Ma}$ (Abu Deif 1992).

Two relatively big siliceous veins mineralized by uranium were detected in El-Missikat area occupying the center of the two main shear zones (El-Missikat shear zone I, and El-Missikat shear zone II) (Fig. 20 a, b and c). These two veins as well as the shear zones are crosscutting metaluminous to slightly peraluminous monzogranite, and have a general ENE trend and dip about $60^{\circ}-70^{\circ}$ toward SSE. The siliceous veins, in general, are irregular in shape and variable in thickness from few centimeters to about 3 meters and extends more than $2 \mathrm{~km}$. Three main types of silica may be distinguished namely : light coloured silica, smoky or black silica, and jasperized silica. The light coloured silica displays various light colours such as white, light grey and pale brown. All these varieties are microcrystalline or crystalline and non mineralized by uranium, they have normal intensity of gamma-radioactivity. The black silica is cryptocrystalline, with brownish, smoky to black colour and mineralized by uranium. The jasperized silica is cryptocrystalline, with deep red colour, it has moderate intensity of gamma-radioactivity, and it is also uranium mineralized. Brecciation is common, in which both black and jasperized silica include sub-angular fragments of the light coloured silica (Abu Dief, 1985).

El Missikat Granite is H-KCA (High-K Calcalkaline), low biotite "7\%" with rare muscovite and low Ca with $\mathrm{Th} / \mathrm{U}$ ratio of about 2.5. It has three phases; started as metaluminous granite and became slightly peraluminous with advanced differentiation. Uranium in this granite type is incorporated mainly in refractory minerals. The presence of numerous and wider alteration zones in El Missikat granite increase its chance for liberating more uranium with respect to G. Gattar U-sites, where the rock is massive and has very narrow alteration zones. Although a considerable alteration processes affected the present granite in comparison with G. Gattar, they may satisfactory to leach enough uranium from the refractory minerals in the granite. It is worthy to mention that the both Kab Amiri, El Sella and El Missikat occurrences are interpreted as vein type mineralization (Ibrahim, 2007). 


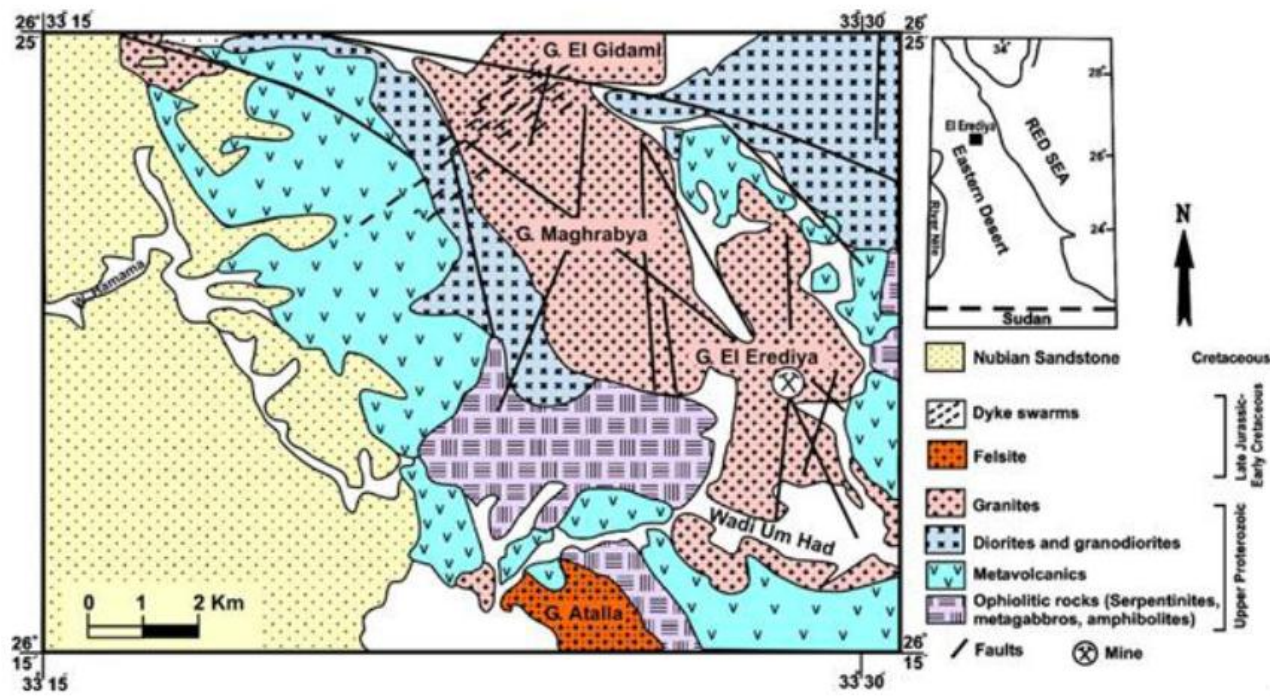

Fig19. Geologic map of the main U-bearing in El-Missikat-El Erediya shear zone (Abu-Deif 1992 and Abd ElNaby, 2008).

Black silica on the other hand is brecciated and invaded by straight and sinuous veinlets of red jasperized silica. Vugs also are common. Empty cubes seem to be present after pyrite crystals which were oxidized and removed; sometimes these cubes are filled with sulphide oxidation products. Black and jasperized silica are the most important from the radioactive point of view because they include all uranium mineralization, mainly sooty pitchblende, uranophane, and sulphides (galena, pyrite, chalcopyrite, sphalerite, molybdenite). Some gangue minerals are found associated with both uranium and sulphides. These ganguges are mainly fluorite (anthozonite), iron oxides and manganese oxides. The average chemical analysis data of the mineralized black and jasperized silica from El-Missikat shear zone is given in Table (3). In addition, Attawiya (1984) concluded that the black silica ranges in U-content from $497-8856 \mathrm{ppm}$.

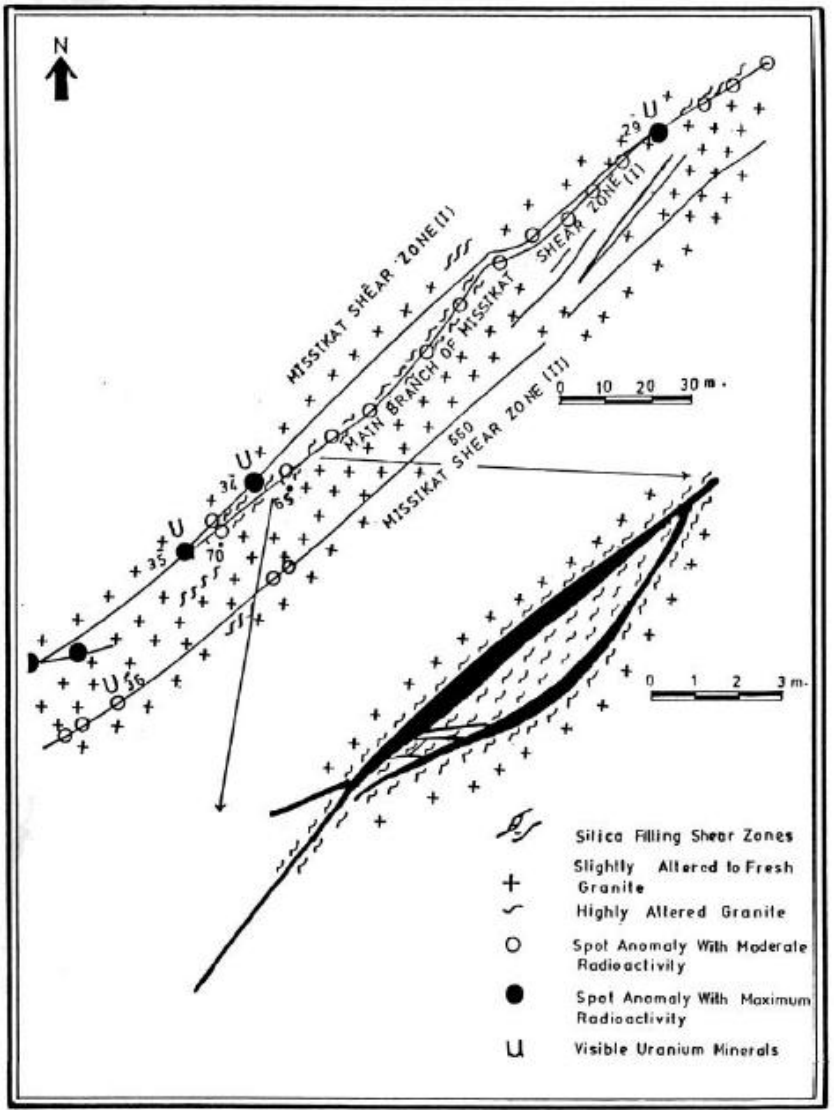

Fig20a. Sketch showing the two main shear zones in El-Missikat U-occurrence and the siliceous veins (after Abu Dief, 1985). 


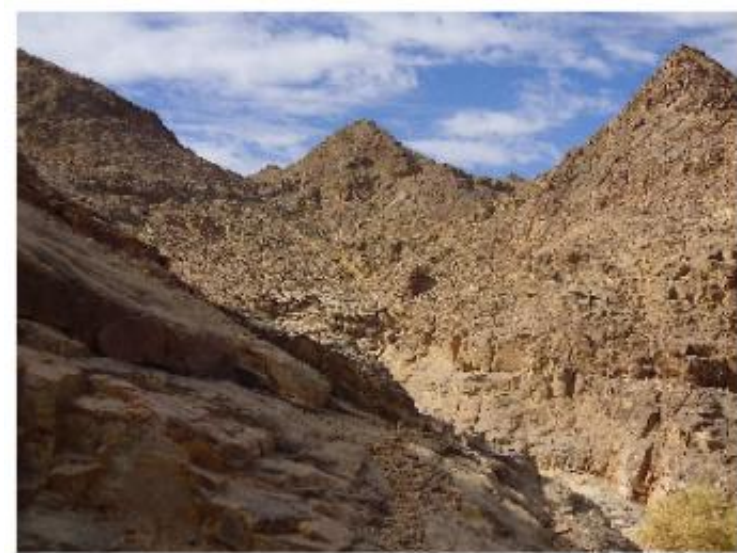

Fig 20b. Veiw showing G. El-Missikat U-occurrence (Photo by G.M.Saleh).

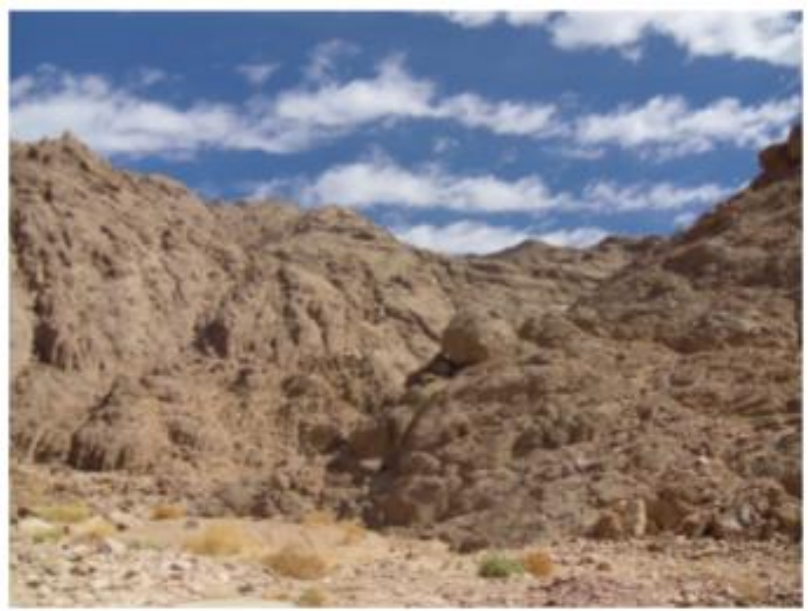

Fig 20c. Veiw showing G. El Erediya uraniferous shear zone (Photo by G.M.Saleh).

Table3. Average chemical analysis data of some trace and rare earth elements of the mineralized silica vein in shear zones.

\begin{tabular}{|l|l|l|l|l|}
\hline Trace / REEs & 1 & 2 & 3 & 4 \\
\hline U & 958 & 937 & 714.4 & 461.9 \\
\hline Th & - & 20.8 & 26.6 & 15 \\
\hline Nb & 200 & 130 & 73.1 & 46.1 \\
\hline Ta & - & 21.4 & - & - \\
\hline SLREE & - & 74.2 & - & - \\
\hline SHREE & - & 2509 & - & - \\
\hline
\end{tabular}

1- Mineralized black silica (after Guirguis, 1981), 2- Silica veins (after Ibrahim, 2002) and 3-\&4-Mineralized silica veins of El-Missikat -El-Erediya (after El-Kammar et al., 1997).

The area is highly altered especially along the structural lines and around the shear zones, the most common alteration are: silicification, sericitization and kaolinitization. The three types of alteration mainly occur in a consistent zonal arrangement in which silicification occurs in the innermost zone followed successively by sericitization and then by kaolinitization. Widespread hematitization and manganese staining are superposed on these alterations.

\section{Genesis of El-Missikat Uranium Deposits}

The uranium-bearing shear-zones were subjected to successive phases of rejuvenation (Abu Dief, 1985 and 1992):

1. Fracturing the granite along ENE-WSW structures.

2. Invasion of these fractures by light coloured silica this might have taken place more than once giving more than on phase of light coloured silica.

3. Rejuvenation of the fractures and brecciation of the light coloured silica and introduction of the black type carrying the uranium-minerals. 
4. In the last stage of rejuvenation, brecciation of earlier silica took place accompanied by the deposition of the red jasperized silica with some uranium minerals.

5. NW-SW faulting leading to displacements and causing off-set of the ENE-WSW shear zone.

6. Uplift and erosion exposed the mineralized shear zones leading to oxidation. Leaching might have taken place causing removal of uranium from the oxidation zone, leaving relics protected by silica.

7. The uranium mineralization of El-Missikat was introduced into the shear zones by the percolation of some sort of hydrothermal fluids, probably mixed with meteoric waters.

\subsubsection{El Sella (Halaib Area), SED, Egypt}

It lies at a distance of about $30 \mathrm{~km} \mathrm{SW}$ of Abu-Ramad city. El-Sella two-mica peraluminous monzogranite is dissected by two-shear zones (5-40 $\mathrm{m}$ in width and $100-1560 \mathrm{~m}$ in length) perpendicular on each others, (ENE-WSW and NNW-SSE) (Ibrahim et al., 2003). These shear zones are mainly composed of highly brecciated sheared fine-grained two-mica monzogranite with muscovite increment at the expense of biotite. They are enriched by pyrite and visible secondary uranium minerals (uranophane and B-uranophane, Assaf et al., 1996 and 1999) and gummite (Saleh, G. M. Personal Communication). Moreover, small quartz veinlets (1-5 cm thick) in various directions invade the shear zones.

The first shear zone (ENE-WSW) extends for about $1560 \mathrm{~m}$ in length $\left(2-40 \mathrm{~m}\right.$ in width) and dips $70^{\circ}$ due to SSE (Fig. 21) (Ibrahim et al., Op. Cit.). From the structural point of view, this shear zone is cut and displaced into three separated parts by two NNW-SSE trending strike-slip faults. Three generations of milky quartz (barren) veins are common; the oldest one, at the shear margins, trending parallel to the shear zone, and dissected by two young generations; NW-SE and N-S with obvious displacement. Red and grey jasperoid (mineralized) veins (0.5-3 m thick, 50-400 m length) are also common (ENE-WSW) parallel to both the shear zone and older milky quartz vein generation, with visible, pyrite and secondary U-minerals. Argillization, fluoritization, hematitization, silicification, carbonization and sulphidization are the main alteration processes (Fig. 22). Acidic dykes (muscovite microgranite) as well as intermediate and basic dykes (amygdaloidal latite and amygdaloidal quartz dolerite respectively) characterized by vugs completely filled by calcite are dominant along ENE-WSW shear zone. The second shear zone (NNW-SSE) extends for a short distance $(100 \mathrm{~m})$ and dips $80^{\circ}$ due to ENE. Also latite (trachyandesite) dyke (chemical trap for uranium) (20$50 \mathrm{~cm}$ thick) is invaded in parallel trend to the shear zone. Along the shear zone, the two-mica monzogranites are highly sheared, kaolinized and completely eroded. The intensity of radioactivity and mineralizations in the first shear zone are very common and more pronounced than the second one. No visible uranium mineralization is recorded in the fresh samples. The excavations revealed the increase of radioactivity all over the trench (up to $7000 \mathrm{ppm} \mathrm{eU}$ ) faces in close contact to silica veinlets with steeply angle of dip $\left(>75^{\circ}\right.$ ) or nearly vertical. Also visible secondary U-minerals appears and increased with depth sporadically on joint surface as well as replacing the oxidized sulphide and filling the vugs. Based on geochemical data, both types of the Sela granites are categorized as peraluminous and were derived from K-rich calc-alkaline magma (Ibrahim et al., 2007). Spectrometric data of the El Sella shear zone in the first, second and third parts were summarized in Table (4).

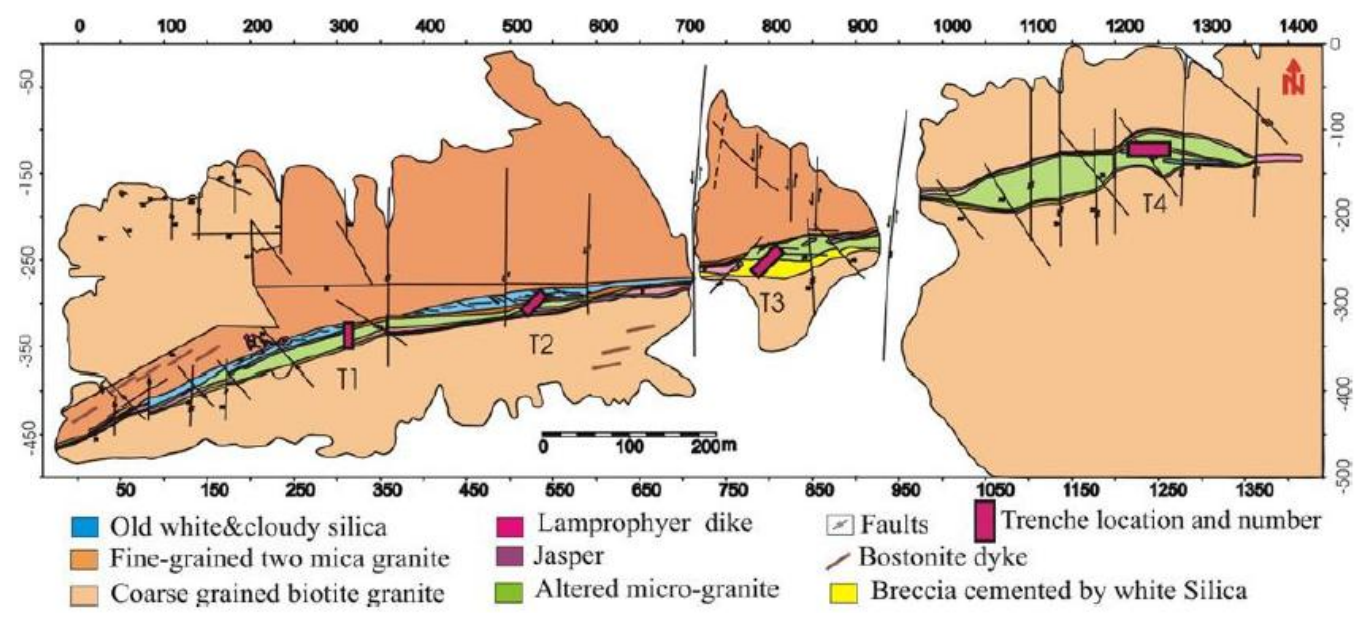

Fig21. Geologic map of ENE-WSW major shear zone of El-Sella (after Ibrahim et al., 2003). 


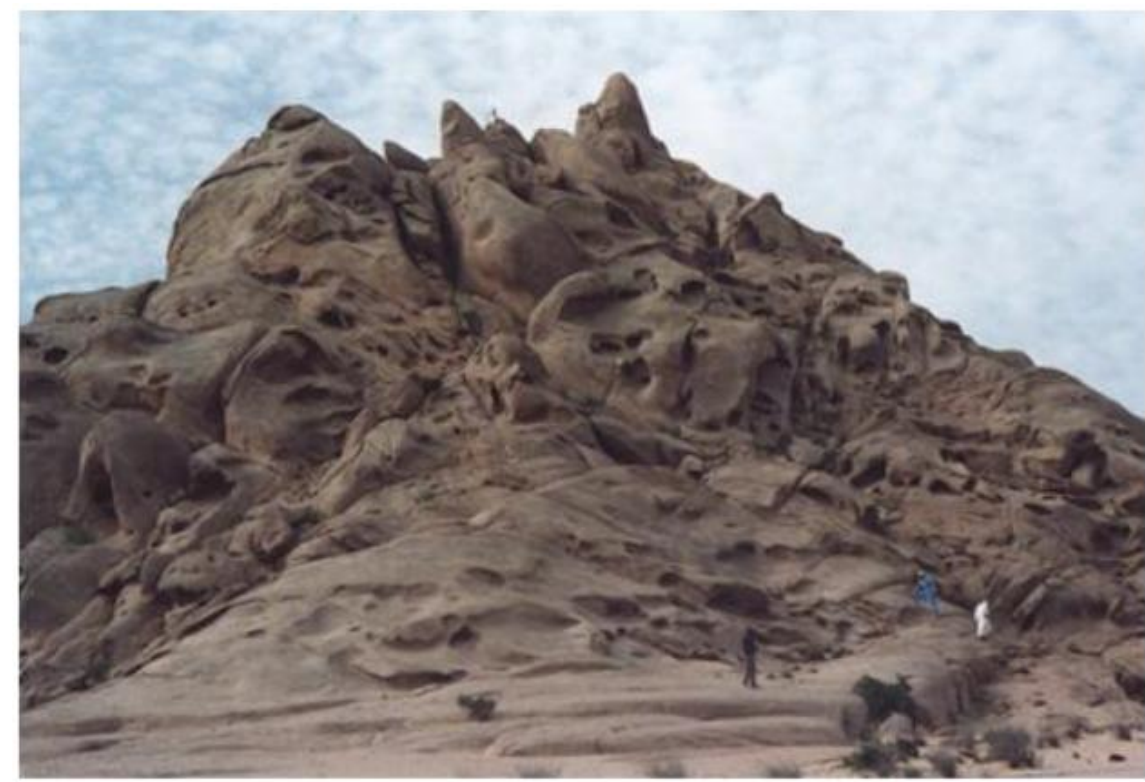

Fig22. View showing exfoliated, cavernous external features due to subsequent weathering processes and fluoritization, hematitization, silicification, carbonization and sulphidization are the main alteration processes in G. Qash Amir younger granites, SED, Egypt. (photo by G.M.Saleh).

Table4. Averages and ranges of eU, eTh (ppm), eU/eTh and K\% contents in the shear zone, El-Sella area.

\begin{tabular}{|c|c|c|c|c|c|}
\hline \multicolumn{2}{|l|}{ Shear zone } & eU (ppm) & eTh (ppm) & eU/eTh & K (\%) \\
\hline \multicolumn{2}{|c|}{$\begin{array}{l}\text { First part } \\
(500 \mathrm{~m})(\mathrm{n}=22)\end{array}$} & $\begin{array}{l}126.7 \\
18-850\end{array}$ & $\begin{array}{l}11.6 \\
1.8-89\end{array}$ & $\begin{array}{l}15 \\
7-55\end{array}$ & $\begin{array}{l}2.3 \\
1.0-8.8\end{array}$ \\
\hline \multicolumn{2}{|c|}{$\begin{array}{l}\text { Second part } \\
(230 \mathrm{~m})(\mathrm{n}=15)\end{array}$} & $\begin{array}{l}49.3 \\
6-194\end{array}$ & $\begin{array}{l}3.7 \\
0.8-9.3\end{array}$ & $\begin{array}{l}13.8 \\
5.5-38\end{array}$ & $\begin{array}{l}1.8 \\
0.8-3.1\end{array}$ \\
\hline \multirow[t]{3}{*}{$\begin{array}{l}\text { Third part } \\
(850 \mathrm{~m})\end{array}$} & $\begin{array}{l}\text { Jasper vein } \\
(n=10)\end{array}$ & $\begin{array}{l}44 \\
15-121\end{array}$ & $\begin{array}{l}3.7 \\
1.2-7.5\end{array}$ & $\begin{array}{l}13.9 \\
2-36.6\end{array}$ & $\begin{array}{l}1.1 \\
0.5-1.9\end{array}$ \\
\hline & $\begin{array}{l}\text { Hematitization } \\
\text { zone } \\
(n=6)\end{array}$ & $\begin{array}{l}33 \\
25-52\end{array}$ & $\begin{array}{l}112 \\
55-155\end{array}$ & $\begin{array}{l}0.32 \\
0.21-0.46\end{array}$ & $\begin{array}{l}3.6 \\
2.6-4.5\end{array}$ \\
\hline & $\begin{array}{l}\text { Argillization zone } \\
(\mathbf{n}=\mathbf{1 0})\end{array}$ & $\begin{array}{l}204 \\
29-991\end{array}$ & $\begin{array}{l}26 \\
2.6-136\end{array}$ & $\begin{array}{l}10.4 \\
4-12\end{array}$ & $\begin{array}{l}3.4 \\
0.7-11.2\end{array}$ \\
\hline
\end{tabular}

$n=$ number of analyses.

El Sella granite is highly fractionated of HKCA magma (High-K Calcalkaline) comprises primary muscovite and represents a granite pluton $\left(80 \mathrm{~km}^{2}\right)$ which was highly affected by weathering processes where the granite appears as isolated "relatively" small masses. The recording of numerous magmatic facies which injected in the area, started by the fine-grained granite enriched in uranium. The microprobe analyses proved the presence of easily leachable (low thorium) primary uranium mineral represented by pitchblende as well as autunite, coffenite and uranophane as secondary uranium minerals (Fig. 23). Some features indicate that the late hydrothermal activities in the mineralized shear zone (ENE-WSW) played an important role in exceeding the U-potentiality (Ibrahim, 2007). These features are summarized as follow:-

1. The abundance of lead, indicating an old mineralization, but has been leached from the primary uranium minerals due to the surface oxidation.

2. The occurrence of strongly altered microgranite within the shear zone.

3. The simultaneous increase of thorium with uranium determined by ground spectrometric measurements which showing as much as $250 \mathrm{ppm}$ eTh correspond to $3000 \mathrm{ppmeU}$. Such features clearly indicate the percolation of late high potential fluid phases in the shear zone. These fluids leading to the simultaneous enrichment of uranium, thorium and may other minerals. Such an enrichment has been also observed from the geochemical analyses of El Missikat silica vein and the illite zone (Ibrahim, et al. 2005).

4. The disequilibrium between the equivalent (>2500 ppm eU) and the elemental uranium (1300 ppm) assures that the majority of the U may concentrated at depth in the ENE-WSW shear zone which acts as good channel and trap. 


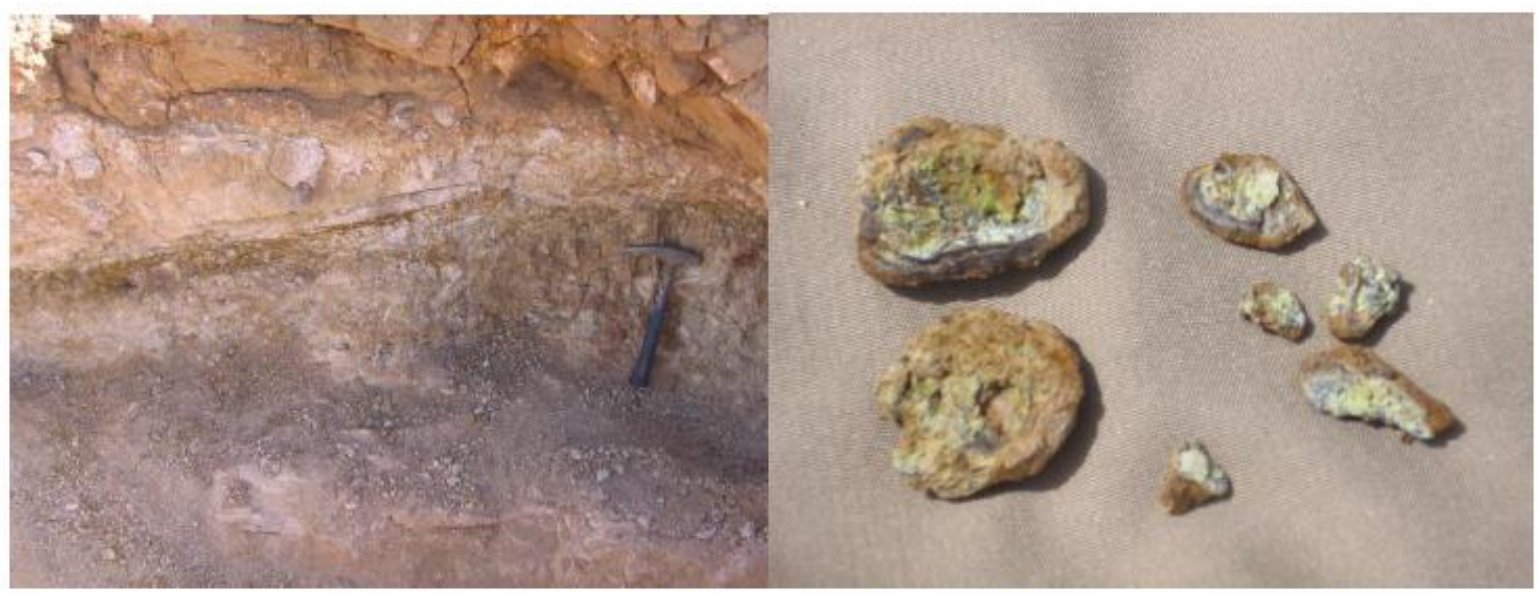

Fig23. Photographs for the mineralized zone (coffenite, uranophane and authunite), in El Sella granite, SED, Egypt (Ibrahim, 2007).

\section{Genesis of El Sella Uranium Deposits}

The El Sella brecciated continuous shear zone is considered as a good trap for uranium mineralization for the following factors (Ibrahim et al., 2003):

1. The high eU contents of the fertile two-mica peraluminous monzogranites (16 ppm eU).

2. The high average of eU/eTh ratio in El Sella shear zone (13.3).

3. A wide barrier of milky silica vein (2-10 m) in El Sella shear zone.

4. The post-magmatic activities are represented by microgranite and dolerite dykes.

5. The chemical trap in El Sella shear zone is represented by basic dykes and tertiary olivine basalt, as well as mafic-ultramafic blocks are in close contact with the shear zone.

6. Tectonically, the fault trends NW-SE and NNW-SSE played at least a role in the remobilization of uranium along the brecciated shear zone.

7. The reducing environment is represented by sulphide minerals and carbonate (calcite pockets).

8. Argillization, hematization, fluoritization, sulphidization and silicification are the main alterations variety containing visible U-minerals.

\subsubsection{Gattar Area, NED, Egypt}

\section{$>$ Gi (G. Gattar) - Uranium Occurrence}

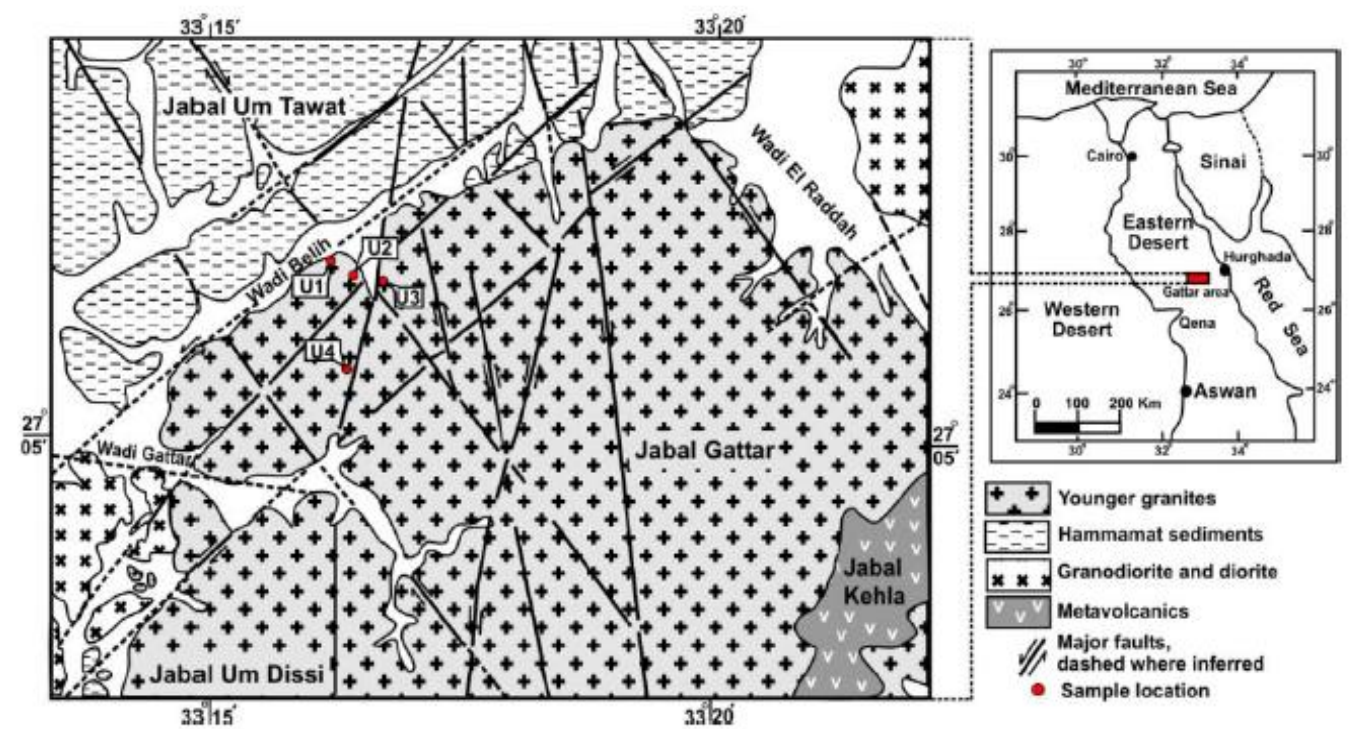

Fig24. Geologic map of the study area (modified from Roz, 1994) and Abd El Naby, 2009. 
A major shear zone (up to $2 \mathrm{~km}$ in length and $0.5-20 \mathrm{~m}$ wide), associated with a N-S to NNE major fracture of $60^{\circ}-70^{\circ}$ angle of dip mainly due to S or ESE directions are crosscutting biotite metaluminous monzogranite. Pale yellow to greenish yellow visible secondary U-minerals (uranophane, soddyite, kasolite, zippite and tyuyamunite) are encountered. The field observations showed that the width of the altered zone, the intensity and distribution of the associated U-minerals as well as the degraded of the accompanied wall rock alterations are gradually increasing upward, towards the northern part of the shear zone. Generally, the concentration of the secondary uranium minerals, along the shear zone, is of discontinuous nature, lensoid in shape and the deposition of uranium mineralization mainly occurred at releasing areas along the strike of the main fault zone (Salman et al., 1987).

The geology of Gattar area, has been extensively studied by many authors (El Shazly, 1970, Dardir and Abu Zied, 1972, Salman et al., 1986, El Rakaiby and Shalaby, 1992, Roz, 1994, Nossier, 1996, Shalaby, 1996). The rock units cropping out at this area are mainly metavolcanics, granodiorites, diorites, Hammamat sediments and younger granites (Fig. 24). Gattar granitic masses are classified as hypersolvus and alkali feldspar granites (El-Sayed et al., 2003). They are red to pink in color and consist mainly of orthoclase and microcline perthites, quartz, biotite and muscovite. Fluorite, zircon, apatite, titanite, galena and ilmenite are observed as accessory minerals. Geochemically, Gattar granites are peraluminous and could be considered as A-type granite (Moussa et al., 2007). The Hammamat sediments reach about $5 \mathrm{~km}$ in width and extend in a nearly east-west direction for about $20 \mathrm{~km}$. They are composed mainly of conglomerates, greywackes and siltstones. These sediments are affected by alteration, including argillization, chloritization and muscovitization of lithic grains, silicification, pyritization followed by pseudomorphic oxidation and hematization. Stern and Hedge (1985) reported a $\mathrm{Rb} / \mathrm{Sr}$ model age of $575 \mathrm{Ma}$ for Gattar granites. However this age is younger than the $206 \mathrm{~Pb} / 238 \mathrm{U}$ crystallization ages (between 597 and $613 \mathrm{Ma}$ ) reported by Moussa et al., (2007). On the other hand, Willis et al. (1988) obtained an age of $585 \pm 15$ Ma for the Hammamat sediments. Presence of some xenoliths of Hammamat sediments in Gattar granites, as well as apophyses and offshoots of the granite mass into the Hammamat sediments, suggests an age younger than $585 \mathrm{Ma}$ that supports the earlier $575 \mathrm{Ma}$ age of Stern and Hedge (1985) and contradicts the recent 597 and 613 Ma ages of Moussa et al., (2007). G. Gattar Granite is a leucocratic H-KCA (High-K Calcalkaline) to alkaline granite. Most of the uranium in this type is associated in refractory minerals and needs complicated alteration processes to form an ore. The U-mineralization was leached with silica from the alteration of the limited fracture walls and redistributed along the contact with the Hmammat sediments due to fluids circulation. Few meters away from the mineralized zones, the granite lacks micro-fractures, alteration and the granite is still highly dense and has low porosity, limiting the chances for U-leaching (Ibrahim, 2007). Table (5) presents the average results of radiometric analysis carried out on 47 selected uraniferous samples.

Table5. Average equivalent uranium-thorium contents (ppm) in the analyzed surface selected from GI and GV occurrences (after Abu Zeid, 1995).

\begin{tabular}{|l|l|l|l|}
\hline No. of Samples & eU $(\mathrm{ppm})$ & eTh $(\mathrm{ppm})$ & Remarks \\
\hline a-GI & & & \\
$1(7)$ & 1180 & 50 & Sheared silicified + hematitized granites. \\
$2(4)$ & 1800 & 45 & Strongly hematitizatied granites. \\
$3(5)$ & 1290 & 35 & Strongly hematitizatied granites. \\
$4(4)$ & 2880 & 75 & Hematitizatied granites + fluorite + smoky quartz. \\
$5(5)$ & 9000 & 75 & Hematitizatied granites + fluorite. \\
\hline b- GV & & & \\
$6(12)$ & 1600 & 12 & Hematitizatied Hammamat sediments. \\
$7(10)$ & 500 & 10 & Hematitizatied episyenites + fluorite. \\
\hline
\end{tabular}

\section{$>$ Gv (G. Gattar) - Uranium Occurrence}

This occurrence represents the most promising and significant uraniferous one in G. Gattar U-prospect. U-minerals here are mainly confined to an altered contact zone between the biotite monzogranites and its bordered Hammamt sediments along W. Bali. The visible secondary U-minerals are distributed along this contact in a separate uraniferous zones ranging in width from 0.5 to $15 \mathrm{~m}$ and in length between 1.2 and $30 \mathrm{~m}$. at the intensely mineralized zones, both biotite monzogranites and the closely adjacent Hammamat sediments are intensely affected by a wide spread deuteric and post magmatic hydrothermal alterations. 
Hematitization, kaolinitization, fluoritization, episyenitization and carbonatization are the most alteration processes. The uranium mineralizations and the various alteration features are usually structurally controlled and accordingly could classify G. Gattar prospect as a hydrothermal vein-type uranium deposits (Abu Zaid, 1995). The presence of uranium mineralizations at different levels confirm the role of ascending hypogene solutions in the biotite monzogranites and their adjacent Hammamat sediments. These features are mostly conformable with that recorded at the different vein-type of the world such as the Boom Lake fault, west of uranium city of Canada and central city district, Colorado, USA (Rich et al., 1975). It is found from the relation between structures and uranium mineralization within the highly promising shear zones are located within a large pull-apart basin (Fig. 25), having about $2 \mathrm{~km}$ length and $500 \mathrm{~m}$ width (Shalaby, 1996).

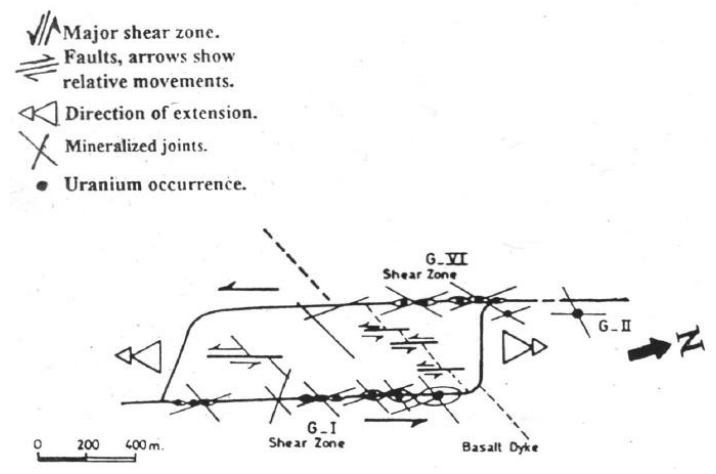

Fig25. Rhomb graben (S-shape) of small size controlling the uranium occurrences of GI, GII, GVI in granites of G. Qattar area (after Shalaby, 1996).

WNW-ESE compression coeval with ENE-WSW extension system has resulted in two sets of conjugate shears. The first trending ENE-WSW is mineralized at El-Missikat and El Sella area, where the orebodies extended in its directon and dissected by the second NNW-SSe left lateral minor fault. However, to the north at G. Gattar area (Shalaby, 1996) the NNW-SSE shear zone is being dominate and characterized by existence of shear-related pull-apart tectonic regime which controlled the uranium mineralization (Fig. 26 a and b).

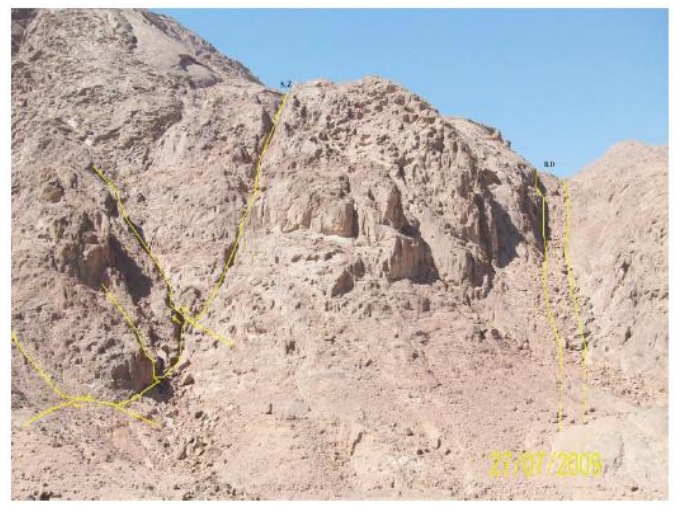

Fig26a. Veiw showing for the NNW-SSE shear zone is being dominate and characterized by existence of shear-related pull-apart tectonic regime which controlled the uranium mineralization, NED, Egypt (Shalaby, 1996).

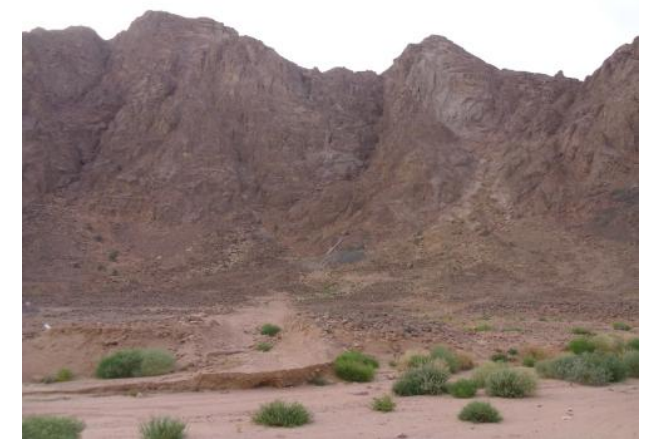

Fig26b. Veiw showing G. Gattar U-prospect (Photo by G.M.Saleh). 


\subsection{Secondary in Metamorphic Rocks}

\subsubsection{Abu Rusheid Brecciated Shear Zone, SED, Egypt.}

The LANDSAT-8 (7, 6, 1 as RGB) FCC image has been applied to discriminate different rock units in Abu Rusheid area including metagabbros, mélange-metasediments, cataclastics and granitic rocks (Fig. 27a). In this band combination image the metagabbros have dark brown color, while the mélange-metasediments appear in dark blue color. Abu Rusheid cataclastic rocks are classified into protomylonite, mylonite, ultramylonite and silicified ultramylonite. The occurrence of uranium resources in Abu Rusheid brecciated shear zone (hematite-rich breccia) is recorded here for the first time since two years ago by Abu Rusheid geologic member. Structural observations in WHC show that the culmination is bounded from east and west by two sub-parallel master left- lateral strike-slip shear zones; namely, Nugrus and El Gemal shear zones (Fig. 27b). The area is crossed by $\mathrm{N}-\mathrm{S}$ to NNW-SSE trending extensional strike-slip fault shear zones with oblique left-lateral dislocation brittle features and ends on the Nugrus shear zone. In addition, the detailed field study recorded the development of ENE-WSW to E-W and/or NE-SW array of strike-slip faults with oblique to dip slip reactivation evidences. The senses of shearing as well as the orientation of these faults indicate that they represent subsidiary R- and P-shears to the NNW-SSE to NW-SE master shear zones (Figs. 27b and 27c). A detailed geological map for Abu Rusheid brecciated shear zone was constructed (Fig. 28a and 28b). The shear zone composed mainly of hematite-rich breccia with approximately $5-40 \mathrm{~m}$ in width, and extends about $1.0 \mathrm{~km}$ in NNW-SSE direction. It is overland by approximately 50 meters of Flat-lying ultramylonites followed by silicified ultramylonites. Rocks of the shear zone are finemedium to coarse grained and characterized by metasomatic alteration, but many of them were subjected to a high degree of erosion. They have different colours (black, whitish pink and red) depending on the degree of alterations, such as, kaolinization, pyritization, silicification, muscovitization, ferrugination, hematitization and advanced argillic altration which are highly predominated. The central core of the brecciated shear zone is highly in specific gravity and rich in hematite ( 7.5 in vol. \% as $\mathrm{FeO}^{\mathrm{t}}$ ) and banded muscovite flanked from the east and west by zones of intermingled hematite-rich breccia and ultramylonite. Post magmatic activity (basic dykes $0.5-1.0 \mathrm{~m}$ in width) in parallel trend to the Abu Rusheid shear zone is predominant. The brecciated shear zone (Figs. 29 and 30) is dissected by ENE-WSW right-hand strike-slip fault with a minor displacement ( 5 $\mathrm{m})$. Iron oxides, zinc, clay minerals, copper, fluorite and manganese oxides are present as thin films along fracture planes clarify the pneumatomatolytic phase. Many vugs are formed in the shear zone as a result of leaching process (Fig. 31).

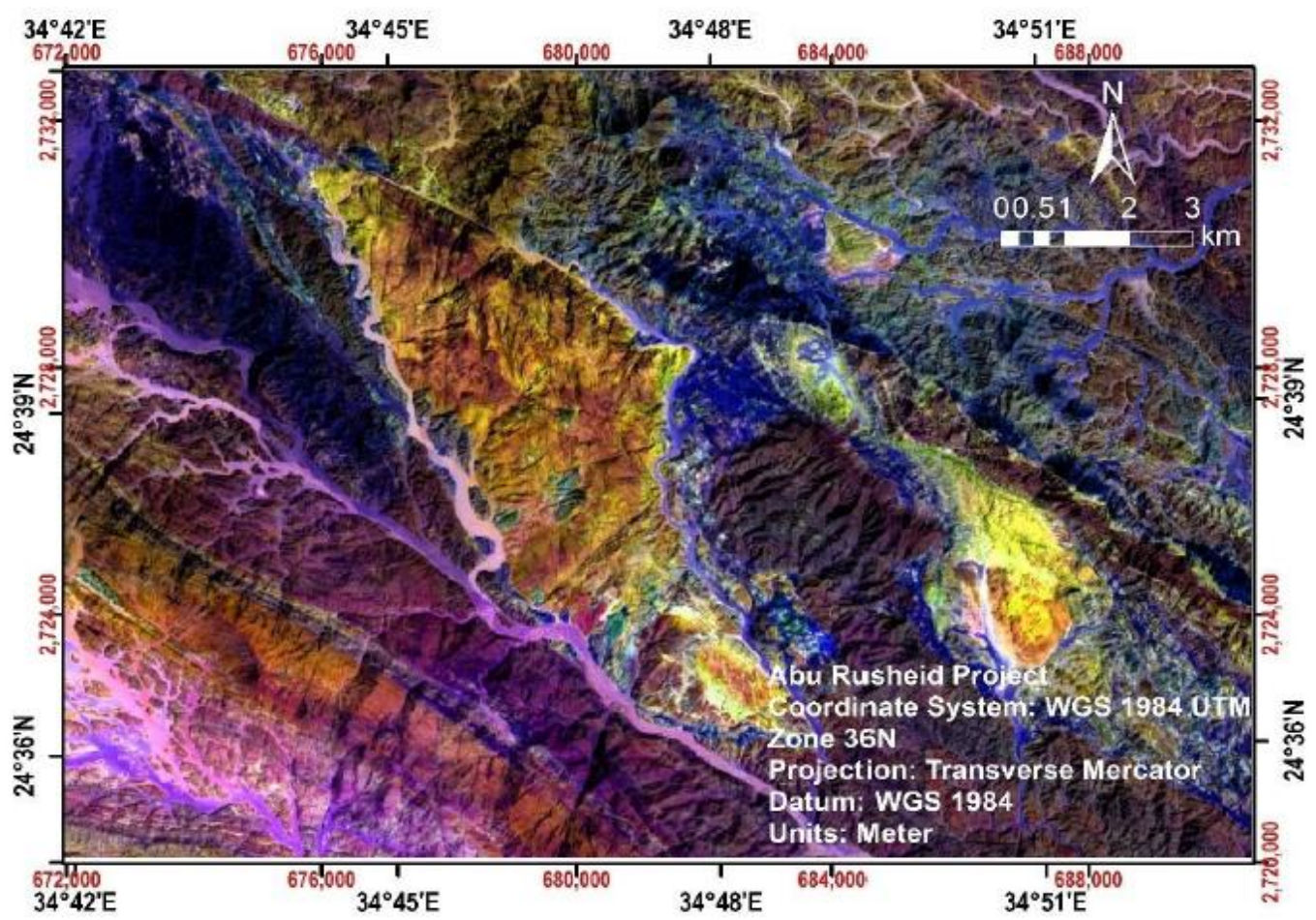

Fig27a. High resolution $R G B(7,6,1)$ false color composite images (FCC) of LANDSAT-8 data enhanced by overlaid Panchromatic band (Band 8), Abu Rusheid area, SED, Egypt. 


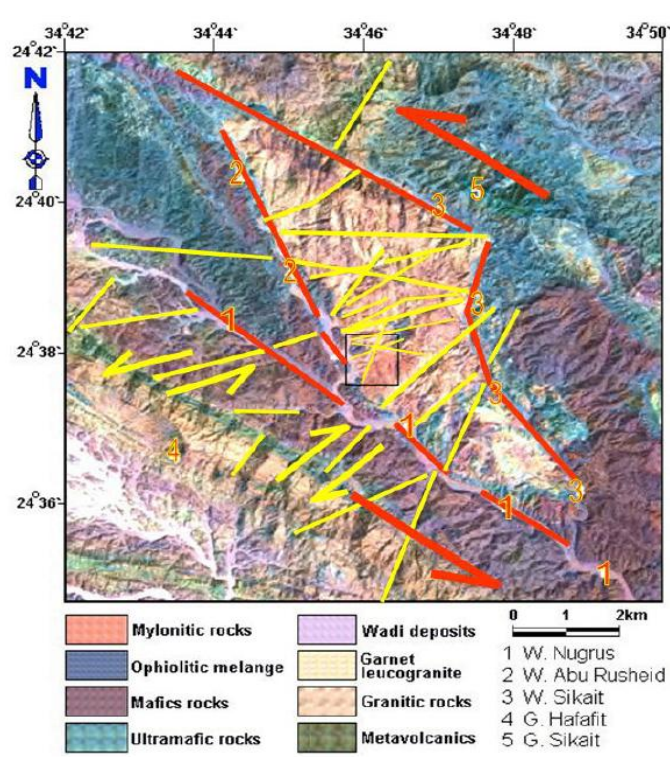

Fig27b. Simplified landsat image showing the regional structural elements of WHC, where the fracture pattern is controlled by the two sub-parallel left-lateral strike-slip shear zones and the development of their subsidiary $R$-and $P$ shears Abu Rusheid area, SED, Egypt (after Saleh et al., 2012).

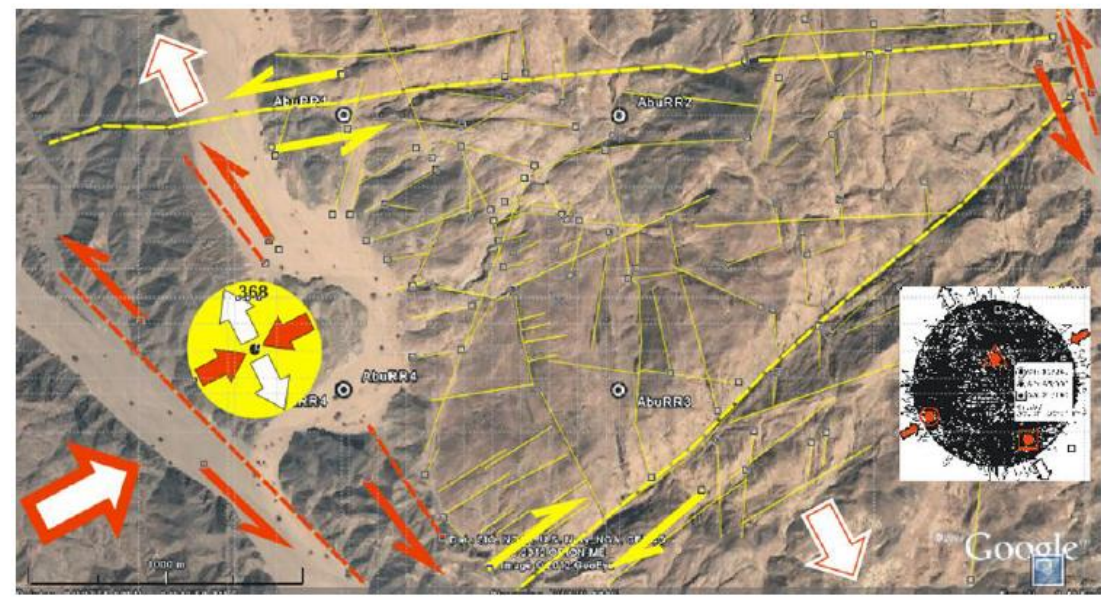

Fig27c. Simplified landsat image showing the structural pattern configuring the project area as well as the deduced paleostress tensor, where the fracture pattern is controlled by the two sub-parallel left-lateral strike-slip shear zones, Abu Rusheid area, SED, Egypt (after Saleh et al., 2012).

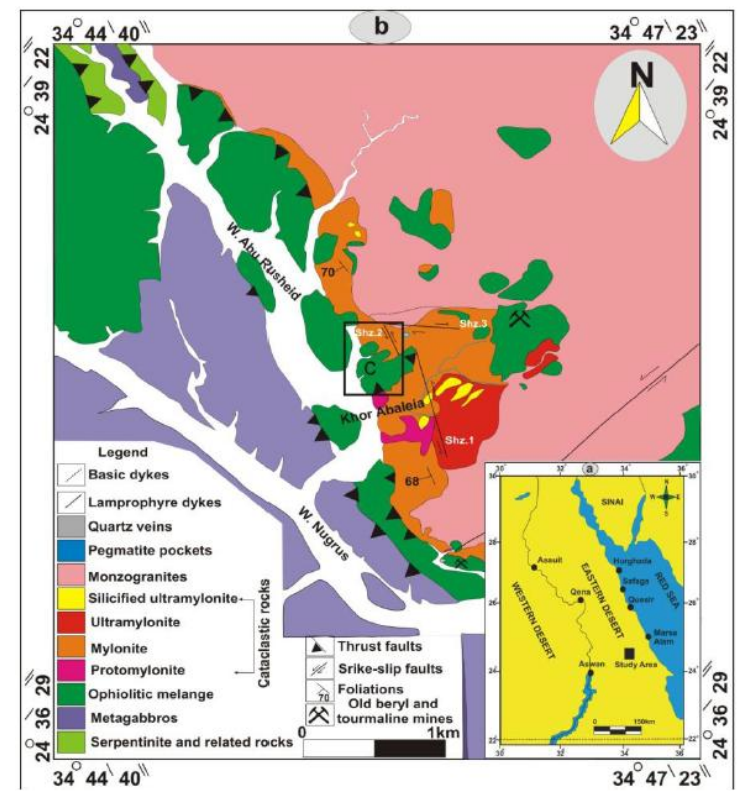

Fig28a. Detailed geologic map of Abu Rusheid shear zones (after Ibrahim et al., 2002 and 2004). 


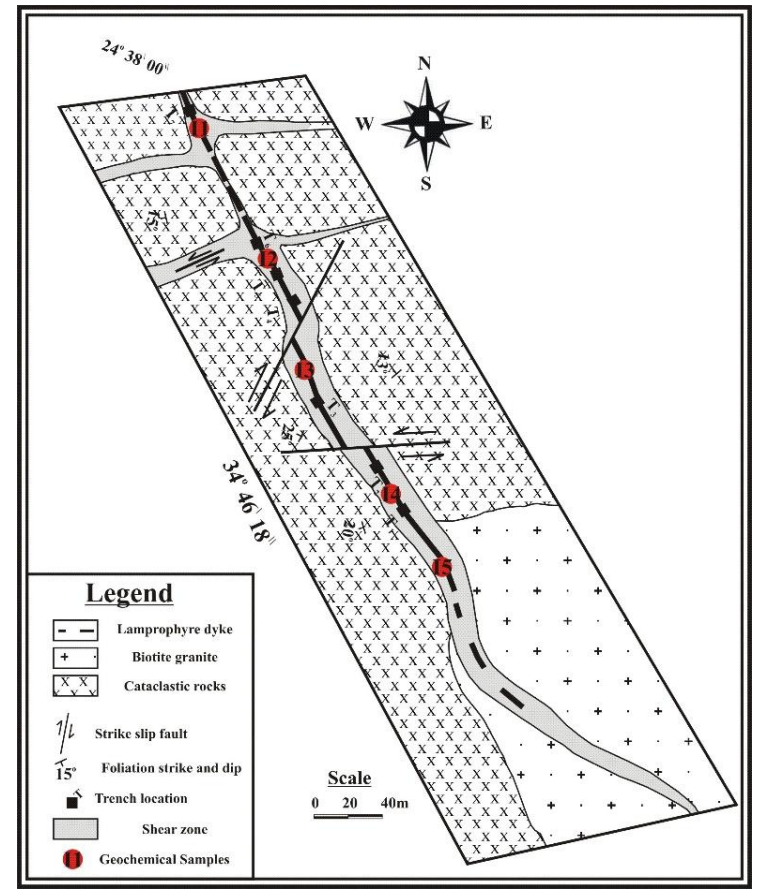

Fig28b. Geologic map of shear zone (I) in Abu Rusheid area, South Eastern Desert, Egypt (after Ibrahim et al., 2004).

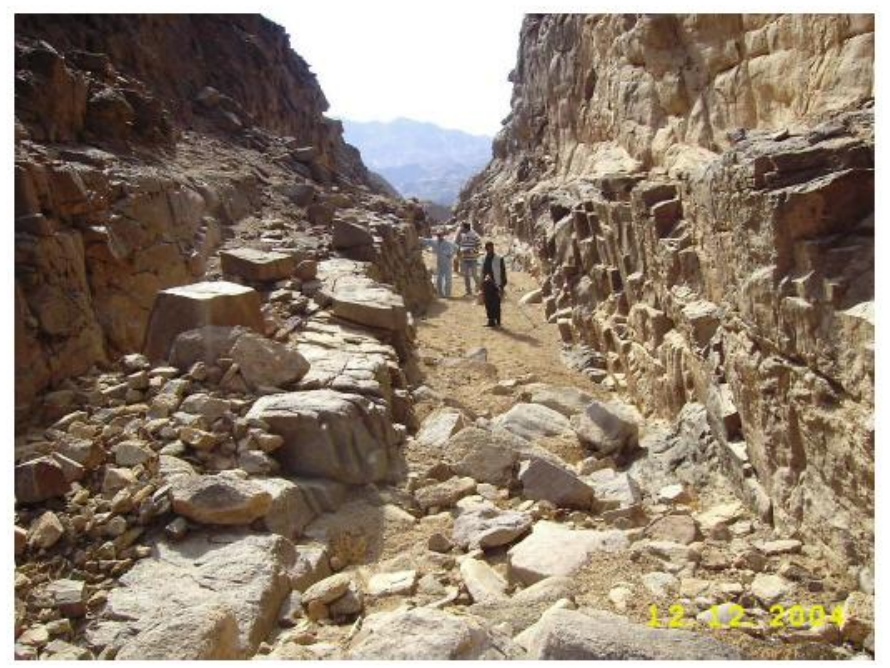

Fig29. Veiw showing for the shear zone is dissected by ENE-WSW right-hand strike-slip fault with a minor displacement, Abu Rusheid area, SED, Egypt (Photo by G.M.Saleh).

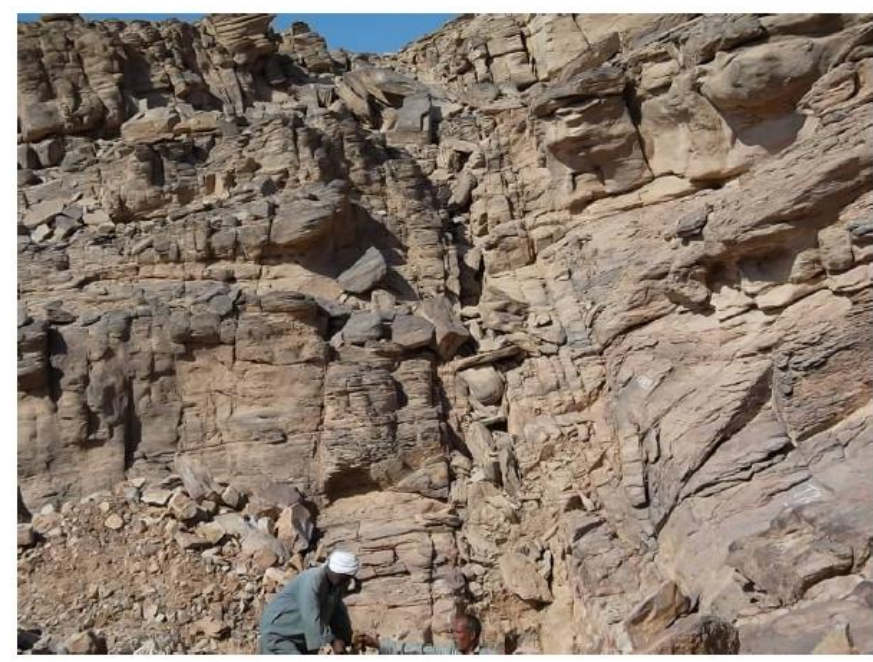

Fig30. Veiw showing for the shear zone is dissected by ENE-WSW right-hand strike-slip fault with a minor displacement, Abu Rusheid area, SED, Egypt (Photo by G.M.Saleh). 


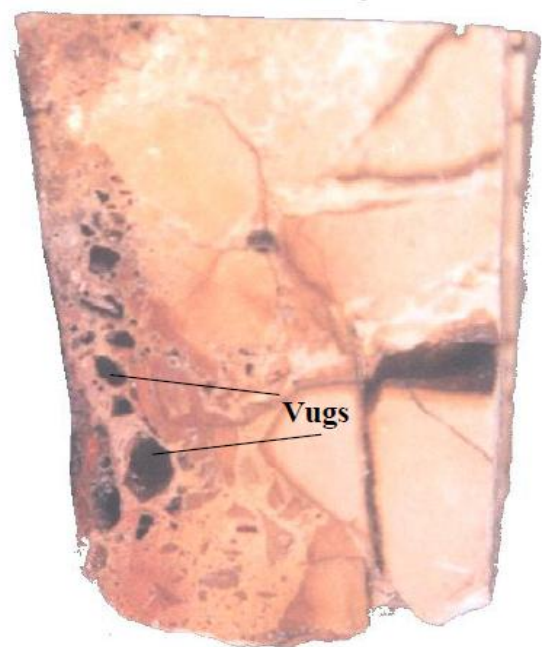

Fig31. Polished slab of Abu Rusheid brecciated shear zone showing hematite-rich breccia and rounded to ellipsoidal vugs, W. Abu Rusheid area, SED, Egypt. (photo by G.M.Saleh).

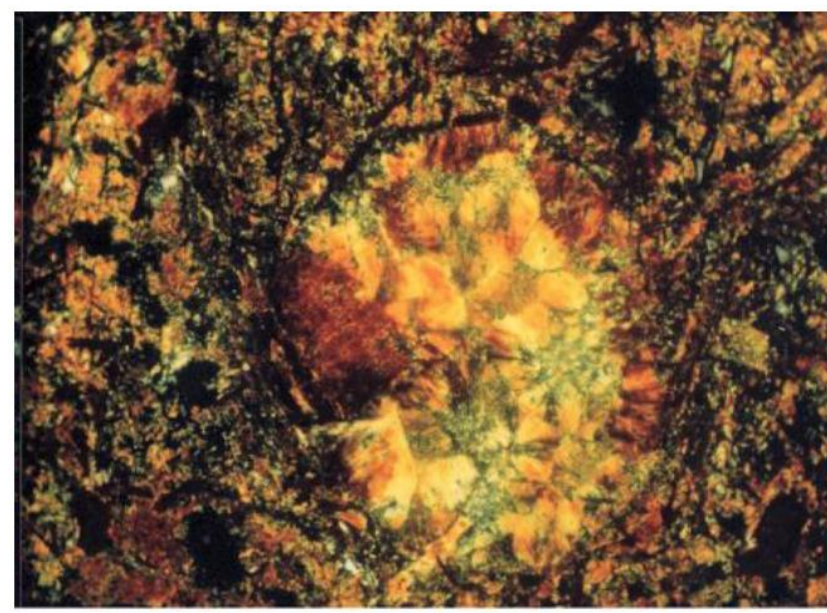

Fig32. Photomicrograph showing rounded to ellipsoidal vugs are filled by calcite and secondary uranium minerals (radial autunite) in corona textures, Abu Rusheid shear zone, SED, Egypt. C.N. $\times 40$

These rounded to ellipsoidal vugs are filled by calcite, adularia and secondary uranium minerals in corona textures (Fig. 32). The zone of silicification is continuous and usually follows the hematitized shear zone. The U-mineralizations in the shear brecciated zone samples are represented by uranophane, coffinite, autunite and gummite (Hassan, M.A., Saleh G. M., Personal Communication), and El-Assay, I.E., Personal Communication), and kasolite together with columbite, sphalerite, arsenopyrite, xenotime, zincite, millerite, willemite, siderite, pyrite and fluorite. These minerals are identified by scan-electron microscope (SEM) and recorded in the brecciated shear zone recently by the Abu Rusheid Project.

The presence of the mineral paragenesis listed above together with the various alterations in the cataclastic rocks indicate that these rocks were subjected to the effect of both mineralizing acidic and alkaline solutions. These mineralizing solutions soaked the rock through fault and foliation planes. The brecciated shear zone may be considered as a potential for several rare metals. The presence of other rare elements of economic significance should also be investigated, e.g. $\mathrm{Zn}, \mathrm{Li}, \mathrm{Ga}, \mathrm{V}$ and REEs, in the brecciated shear zone as well as silver and arsenopyrite in the overlie silicified ultramylonites.

More detailed spectrometric survey has been carried out in the NNW-SSE brecciated shear zone at the central part of the mapped area. The topography of the shear zone increases from north to south. In general, the radioelement concentrations increase at the northern part of the shear zone, especially at the intersection with the E-W Khour Abalea. This fault zone has been subjected to severe alteration, which is responsible for the high potassium metasomatism, especially at the northern part of the shear zone that reach up to $10 \%$ . The eU content ranges from 162 to $1400 \mathrm{ppm}$, whereas eTh content ranges from 115 to $357 \mathrm{ppm}$ and eU/eTh ratio (1.4 to 3.6) are related remobilization and migration of uranium. $U_{\text {chem }} / U_{\text {radio. }}$ Ratio various from the cataclastic host rocks $(<0.1)$ to the discontinuous brecciated shear zone $(>1.6)$ reflecting the 
migration of uranium along the foliations and banding planes from the cataclastic rocks through the channelway of brecciated shear zone. Also, eTh contents along the cataclastic rocks are heterogeneous (larger of smaller than eU) but along the shear zone, eTh usually less than eU contents and sometimes under limit of detection. Also, the field and laboratory examination for each uranium mineralizations in shear zones were summarized in Table (6).

Table6. Classification of U-mineralization in the Egyptian Shear Zones (by G.M. Saleh).

\begin{tabular}{|c|c|c|c|c|c|c|c|}
\hline \multicolumn{2}{|r|}{ Types } & \multirow{2}{*}{\begin{tabular}{|l|}
\multicolumn{1}{|c|}{ Regional Geology } \\
$\begin{array}{l}\text { El-Missikat - El Erediya } \\
\text { granitic pluton is oval } \\
\text { shaped with maximum } \\
\text { length } 12.5 \mathrm{~km} \text { in NW } \\
\text { direction }\end{array}$ \\
\end{tabular}} & \multirow{2}{*}{\begin{tabular}{|l}
\multicolumn{1}{|c}{ Ore Formation } \\
Pitchbelende, \\
uraninite, \\
uranophane, \\
renardite (Abu Dief, \\
1985 \& 1992).
\end{tabular}} & \multirow{2}{*}{ 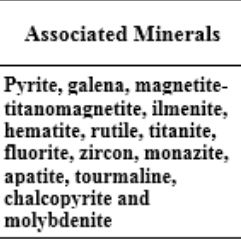 } & \multirow{2}{*}{\begin{tabular}{|l}
\multicolumn{1}{|c|}{ Alteration Processes } \\
$\begin{array}{l}\text { Silicification, } \\
\text { kaolinitization, } \\
\text { sericitization, } \\
\text { hematitization \& } \\
\text { brecciation. }\end{array}$ \\
\end{tabular}} & \multirow{2}{*}{\begin{tabular}{|l|}
\multicolumn{1}{|c}{$\begin{array}{c}\text { Locality of } \\
\text { shear zones }\end{array}$} \\
G. El-Missikat- \\
El Erediya \\
trending shear \\
zone in ENE- \\
WSW, CED, \\
Egypt
\end{tabular}} & \multirow{2}{*}{\begin{tabular}{|l}
\multicolumn{1}{c|}{ Remarks } \\
$\begin{array}{l}\text { Metaluminous to slightly } \\
\text { peraluminous biotite } \\
\text { monzogranite. }\end{array}$
\end{tabular}} \\
\hline \multirow{3}{*}{ 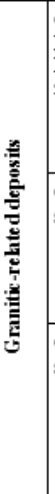 } & $\begin{array}{l}\text { Gabal El- } \\
\text { Missikat - El } \\
\text { Erediya shear } \\
\text { zones }\end{array}$ & & & & & & \\
\hline & $\begin{array}{l}\text { Gabal Sella } \\
\text { shear zones }\end{array}$ & $\begin{array}{l}\text { Ophiolitic mélange, } \\
\text { older granite, Dokhan } \\
\text { volcanics, Molasses } \\
\text { sediments and younger } \\
\text { granites }\end{array}$ & $\begin{array}{l}\text { Uranophane, } \\
\text { autunite and } \\
\text { gummite (Assaf et al., } \\
\text { 1999, Hassan, Saleh } \\
\text { G. M., Personal } \\
\text { Communication) }\end{array}$ & $\begin{array}{l}\text { Pyrite, chalcopyrite, } \\
\text { galena and sphalerite }\end{array}$ & $\begin{array}{l}\text { Argillization, } \\
\text { hematitization, silicification, } \\
\text { pyritization and brecciation }\end{array}$ & $\begin{array}{l}\text { G. Sella (Halaib } \\
\text { area), shear zone } \\
\text { ENE-WSW } \\
\text { trending, SED, } \\
\text { Egypt }\end{array}$ & $\begin{array}{l}\text { Peraluminous two mica } \\
\text { monzogranite }\end{array}$ \\
\hline & $\begin{array}{l}\text { Gabal Gattar } \\
\text { shear zones }\end{array}$ & $\begin{array}{l}\text { Diorite, Dokhan } \\
\text { volcanics, Hammamat } \\
\text { sediments and pink } \\
\text { granites }\end{array}$ & $\begin{array}{l}\text { Uraninite, } \\
\text { uranophane, } \\
\text { soddyite, kasolite } \\
\text { zippeite, tyuyamunite } \\
\text { and schroeckingerite } \\
\text { (Salman et al., 1987 } \\
\text { and Shalaby, 1996). }\end{array}$ & $\begin{array}{l}\text { Calcite, fluorite, hematite, } \\
\text { ilmenite, pyrite, zircon, } \\
\text { molybenite, galena, } \\
\text { chalcopyrite and berryite. }\end{array}$ & $\begin{array}{l}\text { Hematitization, } \\
\text { kaolinitization, } \\
\text { fluoritization, } \\
\text { episyenitization and } \\
\text { carbonitization. }\end{array}$ & $\begin{array}{l}\text { G. Gattar (GI, } \\
\text { GII, GV and } \\
\text { GVI) shear } \\
\text { zones trending } \\
\text { N-S to NNE, } \\
\text { NED, Egypt }\end{array}$ & $\begin{array}{l}\text { 1- Average eU content } \\
3230 \mathrm{ppm} \text { with U-grade } \\
0.32 \% \text { in GI shear zones. } \\
\text { 2- Average eU content } 550 \\
\text { ppm with U-grade } 0.055 \% \\
\text { in GV contact zones. }\end{array}$ \\
\hline 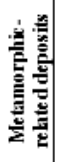 & $\begin{array}{l}\text { Abu Rushied } \\
\text { brcciated } \\
\text { (ductile) shear } \\
\text { zones }\end{array}$ & \begin{tabular}{|l|} 
Layered metagabbros, \\
ophiolitic mélange, \\
protomylonites, \\
mylonites, \\
ultramylonites, silicified \\
ultramylonites and \\
granitoid rocks
\end{tabular} & $\begin{array}{l}\text { Uranophane, } \\
\text { autunite and } \\
\text { gummite (Ibrahim et } \\
\text { al., 2002, Hassan \& } \\
\text { El-Assay, Saleh G. } \\
\text { M., Personal } \\
\text { Communication) }\end{array}$ & $\begin{array}{l}\text { Sphalerite, pyrite, } \\
\text { chalcopyrite, zincite, } \\
\text { arsenopyrite, millerite, } \\
\text { fluorite, franklinite, } \\
\text { willemite, cassiterite, } \\
\text { siderite, xenotime and } \\
\text { ilmenite }\end{array}$ & $\begin{array}{l}\text { Hematite-adularia, } \\
\text { pyritization, silicification, } \\
\text { sericitization, brecciation, } \\
\text { muscovitization, } \\
\text { ferrugination and advanced } \\
\text { argillic alteration }\end{array}$ & $\begin{array}{l}\text { Abu Rushied } \\
\text { shear zone } \\
\text { NNW-SSE, SED, } \\
\text { Egypt }\end{array}$ & $\begin{array}{l}\text { Polymetallic zone (REE, } \\
\mathrm{V}, \mathrm{Ga}, \mathrm{Zn} \text { and } \mathrm{Cu})\end{array}$ \\
\hline
\end{tabular}

\section{RECOMMENDATIONS}

According to the study of uranium mineralization in the shear zones in Egypt, the following conclusions can be outlined:-

1. Abu Rusheid discontinuous shear zone type approaches the first priority U-mineralization and polymetallic zone (REEs, $\mathrm{V}, \mathrm{Ga}, \mathrm{Y}, \mathrm{Pb}, \mathrm{Zn}, \mathrm{Li}$ and $\mathrm{Cu}$ ). The presence of the mineral paragenesis with the various alterations in the cataclastic rocks indicate these rocks were subjected at least to the effect of mineralizing acidic and alkaline solutions. A progress geophysical work and core drilling are recommended along these shear zone to complete the subsurface studies.

Detailed field studies revealed the description of the relations between the lamprophyre dykes and the adjacent host rocks. (after Ibrahim et al., 2004).

a. The Shear zone I having the NNW-SSE direction is found in the cataclastic rocks and biotite granites.

The lamprophyre dyke is extruding in the Shear zone along the zone. This Shear zone varies in thickness from $0.5 \mathrm{~m}$ to $1 \mathrm{~m}$ and up to $800 \mathrm{~m}$ long. The alteration is represented by the sericitization and argilization, as well as hematitization. Visible uranium, manganese and white zinc minerals are distinctive in the Shear zone I lamprophyre.

b. The Shear zone II runs NNW through the low-relief cataclastic rocks, and extends into the two mica granites. It is found far about $200 \mathrm{~m}$ from W. Abu Rusheid and parallel to the first Shear zone. The lamprophyre dyke occurs in the center of the Shear zone NNW-SSE direction, with width ranging from 2 to $5 \mathrm{~m}$. Visible uranium minerals are observed.

c. The Shear zone III is found mainly at the contact between the cataclastic rocks and the two mica granitic rocks in the north of Shear zones I and II. This Shear zone seems as longitudinal trench of V-shape in the ENE-WSW direction. The rocks of Shear zone are characterized by different colours (black, whitish, pink and red) depending on the degree of alterations such as kaolinization and silicification.

2. El Sella continuous shear zone type approaches the second priority U-mineralization, which recorded as the first typical occurrence in Egypt as peraluminous two mica monzogranite.

3. El-Missikat-El Erediya shear zone type approaches the third priority U-mineralization indicate that they were formed through the alteration the original granite (metaluminous to slightly peraluminous) rather than by hydrothermal injection. In this case the hydrothermal origin of these mineralizations may be excluded in this granite and in the similar prospect areas such as G. Gattar. 


\section{REFERENCES}

[1] Abd El-Naby, H.H. (2008): Genesis of secondary uranium minerals associatedwith jasperoid veins, El Erediya area, Eastern Desert, Egypt. Miner Deposita (2008) 43:P. 933-944.

[2] Abu Dief, A. (1992): The relation between the uranium mineralization and tectonics in some Pan-African granite, West Safaga, Eastern Desert, Egypt. Ph.D. Thesis, Faculty of Sci., Assiut Univ., Egypt, 481 p.

[3] Abu Dief, A. (1985): Geology of uranium mineralization in El Missikat, Qena-Safaga road, Eastern Desert, Egypt. M. Sc. Thesis, El Azhar Univ., Cairo, 103 p.

[4] Abu Deif A, Abouelnaga HS, Hassanein HI (2001): Distribution of radioelements and its relation to uranium migration, El Erediya exploratory tunnels, central Eastern Desert, Egypt. J King Abdulaziz Univ (Earth Sci) 13: p. 19-40.

[5] Abu Zaid, M. M. (1995): Relation between surface and subsurface uranium mineralization and structural features, G. Gattar, NED, Egypt. M. Sc. Thesis, Faculty of Science Ain Shams Univ., Cairo, Egypt, 208 p.

[6] Assaf, H. S., Shalaby, M. H., Ibrahim, M. E. and Rasheid, M. A. (1996): Ground radiometric reconnissances survey, shalatin-halaib area, Southeastern Desert, Egypt (Internal Report), 10 p.

[7] Assaf, H. S., Ibrahim, M. E., Amar, S. E., Saleh, G. M. and Rasheid, M. A. (1999): Geological and mineralogical studies on the radioactive mineral occurrence at Qash Amir area, Southeastern Desert, Egypt. (Internal Report), $14 \mathrm{p}$.

[8] Attawiya, M.Y. (1984): On the geochemistry and genesis of the uranium mineralization of El-Missikat area, Egypt : Annals Geol. Surv. Egpt, V. 13, p. $26-38$.

[9] Badham, J. P. N. (1996): Orogenesis and metallogenesis with reference to the silver-nickel, cobalt arsenide ore association. In metallogeny and plate tectonics strong D. F. Ed. Spec. Pap. Geol. Ass. Can., V. 24 , p. $560-571$.

[10] Bain, J. H. C. (1998): Uranium mineralization associated with late Palaeozoic acid magmatism in northeast Queensland. BMR J. Aust. Geol. Geophys., V. 22, p. 137 - 147.

[11] Beck, L. S. (1994): Genesis of uranium in the Athabasca Region and its signification in exploration. Can. Mining Met. Bull., V. 77; p. 367 - 377.

[12] Belevtsev, Y. N. (1980): Endogenic uranium deposits of Precambrian shields: Environment of formation. Assistant Secretary for Resource Applications, Grand Junction Office, Colorado. p. 55 - 80

[13] Billings, M. P. (1972): Structural geology, $3^{\text {rd }}$ ed., Prentice-Hall, Englewood Cliffs, New Jersey, 606p.

[14] Cathelineau, M. (1981): Relations between uranium veins and their host rocks in Vedée and Limousin (France), Mineralogical Magazine, V. 44, p. 417 - 423.

[15] Choukroune, P., Gapais, D. and Merle, O. (1987): Shear criteria and structural symmetry. J. of Structural Geology. V. 9, No. 5/6, p. $525-530$.

[16] Cuney, M. (1978): Geologic environment, mineralogy and fluid inclusions of the Bois Noirs-Limouzat uranium vein, Forez, France. Econ. Geol., V. 73; p. 1567 - 1610.

[17] Dardir, A.A. and Abu Zeid, K.M. (1972): Geology of the basement rocks between lat. $27^{\circ} 00$ and $27^{\circ} 30^{\prime} \mathrm{N}$, Eastern Desert, Annals of Geological Survey of Egypt, 11: p. 129-159.

[18] Dahlkamp, F.J. (1978): Geologic appraisal of the Key Lake U-Ni deposits, Northern Saskatchewan. Econ. Geol., V. 73; p. $1430-1449$.

[19] Dahlkamp, F.J. (1979): Uranium occurrences in northern Saskatchewan, Canada, and their mode of origin, Royal Soc. London, V. 57; p. $131-151$.

[20] Davis, G. H. (2000): Shear zone model for the origin of metamorphic core complexes : Geology, V. 21, p. $348-351$.

[21] Davis, G. H. and Reynolds, S. J. (1996): Structural geology of rocks and regions. $2^{\text {nd }}$ ed., John Wiley \& Sons, Inc., Canada, 776 p.

[22] Dennis, A. J. and Secor, D. T. (2001): A model for the development of crenulations in shear zones with applications from the Southern Appalachian Piedmont : Journal of Structural Geology, V. 19, p. 809 - 817.

[23] El Kassas IA, Bakhit FS (1989): Geology of Wadi Atalla-El Missikat area, Eastern Desert, Egypt. Qatar Univ Sci Bull 9:p. 227-244

[24] El Tahir MA (1985): Radioactivity and mineralization of granitic rocks of El Erediya occurrence and comparison to El Missikat Rei ElGarra occurrence, Eastern Desert, Egypt. Unpublished Ph.D. thesis, AlAzhar University, 132 p.

[25] El Rakaiby, M.L. and Shalaby, M.H. (1992): Geology of Gabal Gattar batholith, Central Eastern Desert, Egypt, International Journal of Remote Sensing, 13: p. 2337-2347.

[26] El Shazly, E.M. (1970): Evolution of granitic rocks in relation to major tectonic, The West Commemoration, 11: 569-581. 
[27] El-Kammar, A.M., El-Hazik, N. and Aly, N. (1997): Geochemistry of accessory minerals associated with radioactive mineralization in the central Eastern Desert, Egypt. J. of African Earth Sci., V. 25, No. 2, p. 237 $-252$.

[28] El-Sayed, M.M., Shalaby, M.H. and Hassanen, M.A. (2003): Petrological and geochemical constraints on the tectonomagmatic evolution of the late Neoproterozoic granitoid suites in the Gattar area, north Eastern Desert, Egypt, N. Jb. Miner. Abh., 178: p.239-275.

[29] Ernst, W. G. (1999): Metamorphism and plate tectonic regimes : Benchmark Papers in Geology : Halsted Press, New York, 440 p.

[30] Ferguson, K. M. (1998): Mineral occurrences and exploration potential of the North Eastern Goldfields. Geological Survey of Western Australia. Report, 70 p.

[31] Gash, S. P. (2001): A study of surface features relating to britle and semi-brittle fracture : Tectonophysics, V. 41 , p. $349-391$.

[32] Gatzweiler, R., Lehnert, T., Clasen, D., Tan, B., Voultsidis, V. and Strnad, J. (1997): The Key Lake uranium nickel deposits. CIM, V. 92; p. $73-79$.

[33] Guirguis, L. A. (1981): Acid leaching of uranium from G. El-Missikat in the Central Eastern Desert, Egypt. Internal Report, NMA, Cairo, 13 p.

[34] Hanmer, S. and Passchier, C. (2000): Shear-sense indicators : a review : Geological survey of Canada Paper 17, 72 p.

[35] Hussein HA, Hassan MA, El Tahir MA, Abu-Deif A (1986): Uranium bearing siliceous veins in younger granites, Eastern Desert, Egypt, Report of the working group on uranium geology, IAEA, Vienna, TECDOC 361:p.143-157

[36] IAEA (Fuchs H ed.) (1986): Vein-type uranium deposits, TECDOC-361, IAEA, Vienna, 423 p.

[37] Ibrahim, M. E. and others (2002): Uranium and the associated rare metals potentialities of Abu Rushied brecciated shear zone, South Eastern Desert, Egypt (Abu Rushied Project, NMA; Internal Report), 110 p.

[38] Ibrahim, M.E., Saleh, G.M., Ibrahim, I.H., Amer, T, Mahmoud, F.O., Abu El Hassan, A.A., Aly, M.A., Azab, M.S., Rashed, M.A., Khaleal, F.M. and Mahmoud, M.A., 2004: Uranium and associated rare metals potentialities of Abu Rusheid brecciated shear zone II, south Eastern Desert, Egypt. (Internal report), $135 \mathrm{p}$.

[39] Ibrahim, M. I., Zalata, A.A., Assaf, H. S., Ibrahim, I. H and Rasheid, N. A. (2003): El-Sella shear zone, southeastern Desert, Eygpt : An example of vein-type uranium deposits. Egypt. J. Geol. (in press).

[40] Ibrahim, T. M. (2002): Geologic and radioactive studies of the basement-sedimentary contact in the area west G. El-Missikat, Eastern Desert, Egypt. Ph. D. thesis, Mansoura University, Fac. Sci., Egypt. P. 214.

[41] Ibrahim, T. M. M.; Cuney, M.; Ali, K. G.; Abdel Meguid, A. A; Gaffar, I, M.; Shahin H.; Omar, S. A., Masoud, S. M.; Haridy, H. M.M., (2005): The U-fertility Criteria Applied to El Sela Granite, South Eastern Desert, Egypt. International Symp. Uranium Production and Raw Materials for the Nuclear Fuel Cycle, IAEA,Vienna, Austria, 20-24 June 2005, p. 100-103.

[42] Ibrahim, T. M. M. (2007): Uranium Geology with emphasize on the effect of the alteration processes. (Abu Rmad Project, NMA; Internal Report), 26 p.

[43] Krishna, R. N., Sunilkumar, T. S. and Narasimhan, D. (1999): Gold in copper-uranium ores of Singhbhum shear zone, Bihar, India. J. of the Geological Society of India, V. 54, p. 37 - 42.

[44] Li Tiangang, H. Z. (1986): Vein uranium deposits in granites of Xiazhuang ore field. Report of the working group on uranium geology organized by the IAEA, Vienna, p. $359-376$.

[45] Mathews, G. W. (1978): Uranium occurrences of uncertain genesis, in : .Mickle, D. G. and Mathews, G. W. eds., Geologic Characteristics of environments favorable for uranium deposits US-DOE, GJBX-67(78), p. 221-250.

[46] McMillian, R. H. (1996): Classical uranium veins. British Columbia Mineral Deposits, Profiles, V. 2, p. 93 - 96.

[47] McMillian, R. H. (1998): Unconformity-associated U. British Columbia Mineral Deposit Profiles, V. 4, p. 87 - 99.

[48] Meyer, C. and Hemley, J. J. (1967): Wall rock alteration, in Barnes, H. L., Ed., Geochemistry of hydrothermal ore deposits, New York, Holt, Rinehart and Winston, p. 166 - 235.

[49] Moussa, E.M., Stern, R.J., Manton, W.I. and Ali, K.A. (2007): SHRIMP zircon dating and Sm/Nd isotopic investigations of Neoproterozoic granitoids, Eastern Desert, Egypt, Precambrian Research, 160: p. 341-356.

[50] Nossier, L.M. (1996): U-F bearing episyenitized "desilicified" granitic rocks of Gabal Gattar, north Eastern Desert, Egypt, Egyptian Academy of Sciences, 46: p. 375-396.

[51] Oliver, N. H. S., Pearson, P. J., Holcombe, R. J. and Ord, A. (1999): Mary Kathleen metamorphichydrothermal uranium rare earth element deposit; ore genesis and numerical model of coupled deformation and fluid flow. Australian J. of Earth Science, V. 46, p. 467-484. 
[52] Osmond JK, Dabous AA, Dawood YH (1999): U series age and origin of two secondary uranium deposits, central Eastern Desert, Egypt. Econ Geol 94: p. 273-280

[53] Rich, R. A., Holland, H. D. and Peterson, U. (1975): Vein-type uranium deposits : U.S. energy research and develop. Adm., GJO-1640, Harvard Univ., Dep. Geol. Sci. Cambridge, Massachusetts, 383 p.

[54] Robinson, B. W. and Ohmoto, H. (1990): Mineralogy, fluid inclusions, and stable isotopes of the Echo Bay U-NiAg-Cu deposits, North-West Territories, Canada. Econ. Geol., V. 88, p. 635 - 656.

[55] Roz, M.E. (1994): Geology and uranium mineralization of Gabal Gattar, north Eastern Desert, Egypt. M.Sc. Thesis, Cairo University, $175 \mathrm{p}$.

[56] Ruzicka, V. (1993): Vein uranium deposits; Ore geology reviews, V. 8, p. 247 - 276.

[57] Salman, A. B., El Assay, I. E. and Shalaby, M. H. (1987): New occurrence of uranium mineralization in G. Gattar Northern Eastern Desert, Egypt. Ann. Geol. Surv. of Egypt. V. 16, p. 31-34.

[58] Sassano, G. P., Fritz, P. and Morton, R. D. (1972): Paragenesis and isotopic composition of some gangue minerals from the uranium deposits of Eldorado, Saskatchewan. Can. J. Earth Sci., V. 9, p. 141 - 157.

[59] Shalaby, M. H. (1996): Structural controls of uranium mineralization at G. Gattar, North Eastern Desert, Egypt. Proc. Egypt. Acad. Sci. V. 46, p. 521 - 536.

[60] Stern, R.J. and Hedge, G.E. (1985): Geochronologic and isotopic constraints on Late Precambrian crustal evolution in the Eastern Desert of Egypt, Amer. J. Sci., 285: p. 97-127.

[61] Twiss, R. J. and Moores, E. M. (1992): Structural geology: W. H. Freeman and Company, New York, $532 \mathrm{p}$.

[62] Wallace, A. R. and Whelan, J. F. (1986): The Schwartzwalder uranium deposit, III: Alteration, vein mineralization, light stable isotopes, and genesis of the deposit. Econ. Geol., V. 81; p. $872-888$.

[63] Wheatley, K. Murphy, J., Leppin, M., Cutts, C. and Climie, J. A. (1999): Advances in the genetic model and exploration techniques for unconformity-type uranium deposits in the Athabasca Basin. Special Publication-Saskatchewan Geological Society, V. 14, p. 126-136.

[64] Woodcock, N. H. and Fischer, M. (2002): Strike-slip duplexes. Journal of Structural Geology, V. 20, p. $725-735$.

[65] Willis, K.M., Stern, R.J. and Clauer, N. (1988): Age and geochemistry of late Precambrian sediments of Hammamat series from the north of Eastern Desert of Egypt, Precambrian Research, 42: p. 173-187

[66] Yadava, R. S. (1995): Uranium-gold mineralization around "Horse" structure in the Proterozoic rocks of Rampur Group in Munish-Kaladi area, Shimla district, Himachal Praclesh, India, J. of Himalayan Geology, V. 6, p. $17-22$.

Citation: Gehad M. Saleh, "Uranium Mineralization in Shear Zones: An Overview ", International Journal of Mining Science (IJMS), vol. 6, no. 1, pp. 37-64, 2020. Available: DOI: http://dx.doi.org/ 10.20431/24549428.0601004

Copyright: (C) 2020 Authors. This is an open-access article distributed under the terms of the Creative Commons Attribution License, which permits unrestricted use, distribution, and reproduction in any medium, provided the original author and source are credited. 